\title{
AVALIAÇÃO FÍSICO-QUÍMICA DE CACHAÇAS COMERCIAIS E ESTUDO DA INFLUÊNCIA DA IRRADIAÇÃO SOBRE A QUALIDADE DA BEBIDA EM TONÉIS DE CARVALHO
}

\author{
MARIANA BRANCO DE MIRANDA
}

Dissertação apresentada à Escola Superior de Agricultura "Luiz de Queiroz”, Universidade de São Paulo, para obtenção do título de Mestre em Ciências. Área de Concentração: Ciência e Tecnologia de Alimentos.

P I R A C I C A B A

Estado de São Paulo - Brasil

Agosto - 2005 


\title{
AVALIAÇÃO FÍSICO-QUÍMICA DE CACHAÇAS COMERCIAIS E ESTUDO DA INFLUÊNCIA DA IRRADIAÇÃO SOBRE A QUALIDADE DA BEBIDA EM TONÉIS DE CARVALHO
}

\section{MARIANA BRANCO DE MIRANDA}

Engenheiro de Alimentos

\author{
Orientador: Prof. Dr. ANDRÉ RICARDO ALCARDE
}

\begin{abstract}
Dissertação apresentada à Escola Superior de Agricultura "Luiz de Queiroz”, Universidade de São Paulo, para obtenção do título de Mestre em Ciências. Área de Concentração: Ciência e Tecnologia de Alimentos.
\end{abstract}

P I R A C I C A B A

Estado de São Paulo - Brasil

Agosto - 2005 
Dados Internacionais de Catalogação na Publicação (CIP) DIVISÃO DE BIBLIOTECA E DOCUMENTAÇÃO - ESALQ/USP

Miranda, Mariana Branco de

Avaliação físico-química de cachaças comerciais e estudo da influência da irradiação

sobre a qualidade da bebida em tonéis de carvalho / Mariana Branco de Miranda. - Piracicaba, 2005.

$70 \mathrm{p}$.

Dissertação (Mestrado) - - Escola Superior de Agricultura Luiz de Queiroz, 2005.

1. Bebidas alcoólicas - Qualidade 2. Cachaça - Propriedades 3. Físico-química

4. Irradiação 5. Maturação I. Título

CDD 663.53

"Permitida a cópia total ou parcial deste documento, desde que citada a fonte - O autor" 
Aos MeUs paIs José E IRACEMA, PELO AMOR, EDUCAÇÃO, CONFIANÇA E DEDICAÇÃO AOS MEUS IRMÃOS ANDRÉ E VITOR, PELA AMIZADE E INCENTIVO DEDICO AO MEU PRIMO MARCELO SPRUCK (IN MEMORIAN), POR ESTAR SEMPRE PRESENTE OFEREÇO 


\section{AGRADECIMENTOS}

À Deus, pela vida e por mais essa vitória;

Ao meu pai, pelo exemplo de pessoa e de pesquisador;

À minha mãe, pelo estímulo e dedicação;

Aos meus irmãos André e Vitor, e à minha cunhada Luciany, pelo apoio em todos os momentos;

Às minhas avós Olga, pela tranqüilidade e valiosos conselhos, e Helena (in memorian), pela serenidade transmitida;

Ao Thiago dos Santos pelo carinho, paciência e compreensão;

Ao Prof. Dr. André Ricardo Alcarde, pela orientação, incentivo e amizade durante a realização desta pesquisa;

Ao Prof. Dr. Jorge Horii, pelas sugestões e dedicação na conclusão deste trabalho, pela amizade e confiança;

À Prof ${ }^{\mathrm{a}}$. Dra. Marta Helena Filetti Spoto, pelo auxílio na elaboração da análise sensorial;

Ao Prof. Dr. Vanildo Luiz Del Bianchi, pelos ensinamentos e por fazer parte da minha colcha de retalhos;

À FAPESP, pela concessão de recursos para a realização deste projeto; 
Aos técnicos de laboratório, principalmente Regina Helena Gonçalves pelo auxílio nas análises;

Ao Dr. Antônio Sampaio Baptista pela colaboração nas análises estatísticas;

Às bibliotecárias Beatriz Helena Giongo e Midiam Gustinelli, pelo auxílio técnico no decorrer do curso e pela revisão deste trabalho;

À todos os funcionários do Departamento de Agroindústria, Alimentos e Nutrição, pela atenção;

À todos que participaram da análise sensorial;

Ao CENA, pela oportunidade da realização de parte deste projeto;

Às amigas do curso Flavia, Ana Paula, Patrícia e Márcia, por todas as alegrias compartilhadas; e à Thaís, pela cumplicidade e apoio;

À Ana Claudia Cayres de Mendonça, pela fundamental colaboração na execução da análise sensorial, e principalmente pelo companheirismo e dedicação;

À Aline Brigato Abreu da Silva, pela amizade incondicional;

Aos colegas de trabalho Maria Beatriz, Ivan, Daniele e Vitor, pelo carinho e incentivo, e ao Prof. Edson de Souza, pela oportunidade e compreensão;

À todos que contribuíram direta ou indiretamente para a realização deste trabalho. 


\section{SUMÁRIO}

Página

LISTA DE FIGURAS................................................................................... viii

LISTA DE TABELAS .................................................................................. ix

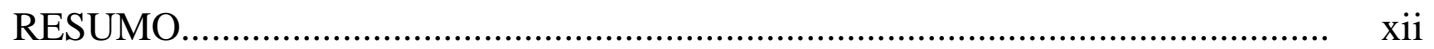

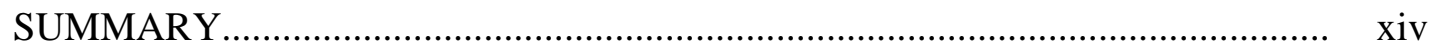

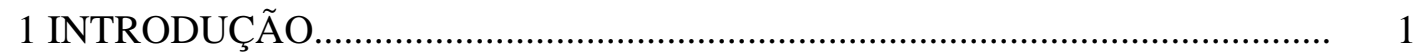

2 REVISÃO DE LITERATURA....................................................................... 3

2.1 Cachaça................................................................................................................... 3

2.2 Caracterização da aguardente e da cachaça......................................................... 4

2.3 Processo de produção.......................................................... 8

2.3.1 Matéria-prima...................................................................................... 8

2.3.2 Fermentação e destilação............................................................................... 8

2.3.3 Componentes secundários............................................. 11

2.3.4 Qualidade da cachaça.......................................................................................... 13

2.3.5 Envelhecimento................................................................................... 14

2.3.6 Técnicas modernas de envelhecimento de bebidas....................................... 16

3 MATERIAL E MÉTODOS............................................................ 18

3.1 Levantamento da qualidade............................................................................. 18

3.1.1 Análises físico-químicas........................................... 19

3.1.2 Análises cromatográficas........................................... 19

3.1.3 Análise estatística.................................................................................. 20

3.2 Envelhecimento de cachaça pela radiação gama e pela madeira carvalho......... 20

3.2.1 Irradiação ................................................................................. 21 
3.2.2 Análises físico-químicas......................................................................... 21

3.2.3 Análises cromatográficas............................................................................... 22

3.2.4 Análise sensorial............................................................................... 22

3.2.5 Análise estatística................................................................................. 24

4 RESULTADOS E DISCUSSÃO.................................................................... 25

4.1 Levantamento da qualidade das cachaças.............................................................. 25

4.2 Comparação entre cachaças envelhecidas após diversos tratamentos................. 42

4.2.1 Grau alcoólico....................................................................................... 48

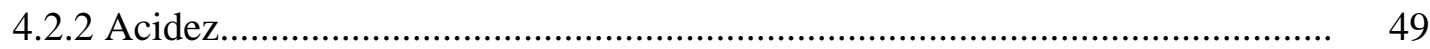

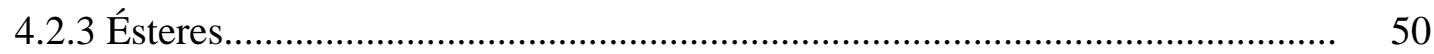

4.2.4 Aldeídos.............................................................................................. 51

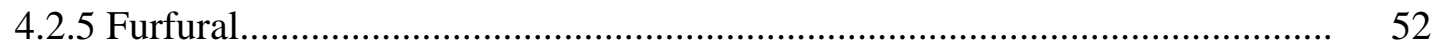

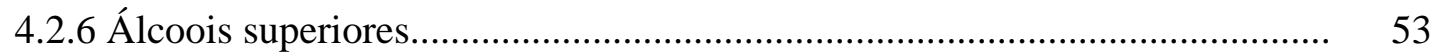

4.2.7 Coeficiente de congêneres.............................................................................. 54

4.2.8 Álcool metílico........................................................................................ 55

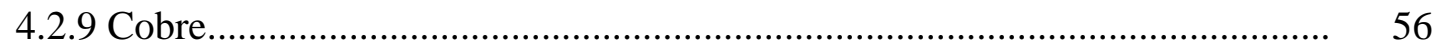

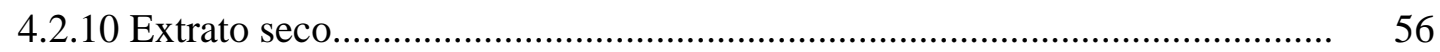

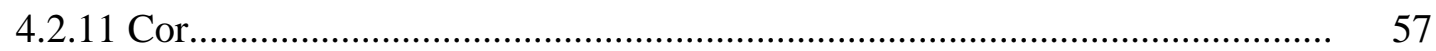

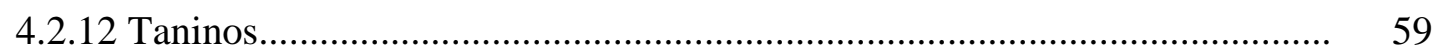

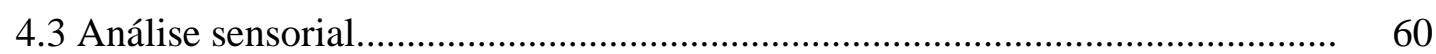

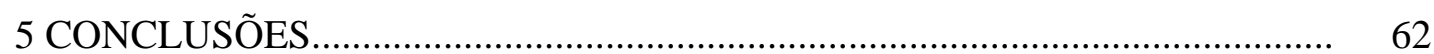

REFERÊNCIAS BIBLIOGRÁFICAS......................................................... 63 


\section{LISTA DE FIGURAS}

Página

1 Fluxograma de produção da cachaça................................................................ 10

2 Modelo de ficha utilizada na avaliação no Teste de Aceitação............................ 23 


\section{LISTA DE TABELAS}

Página

1 Características físicas e químicas para a aguardente de cana-de-açúcar, estabelecidas pela legislação brasileira (Brasil,1974).....

2 Características físicas e químicas para a aguardente de cana-de-açúcar e cachaça, estabelecidas pela legislação brasileira (Brasil, 2005).

3 Composição físico-química de cachaças comerciais........................................ 26

3.1 Composição físico-química de cachaças comerciais......................................... 27

3.2 Composição físico-química de cachaças comerciais......................................... 28

3.3 Composição físico-química de cachaças comerciais........................................ 29

3.4 Composição físico-química de cachaças comerciais........................................ 30

3.5 Composição físico-química de cachaças comerciais........................................ 31

3.6 Composição físico-química de cachaças comerciais........................................ 32

3.7 Composição físico-química de cachaças comerciais......................................... 33

3.8 Composição físico-química de cachaças comerciais........................................ 34

3.9 Composição físico-química de cachaças comerciais......................................... 35

3.10 Composição físico-química de cachaças comerciais....................................... 36

3.11 Composição físico-química de cachaças comerciais........................................ 37

4 Número de amostras de cachaça que não atenderam ao respectivo padrão de identidade e qualidade estabelecido pela legislação brasileira............................ 39

5 Composição físico-química média das cachaças analisadas, incluindo o desvio padrão dos componentes das amostras de cachaça............................................... 40

6 Composição físico-química das cachaças com e sem irradiação, sem contato com a madeira 
7 Composição físico-química da cachaça sob processo de envelhecimento em madeira carvalho sem irradiação.

8 Composição físico-química da cachaça sem irradiação sob processo de envelhecimento em madeira carvalho irradiada.

9 Composição físico-química da cachaça irradiada sob processo de envelhecimento em madeira carvalho sem irradiação.

10 Composição físico-química da cachaça e da madeira carvalho com irradiação.

11 Médias dos tratamentos que a cachaça foi submetida durante o período total de envelhecimento para grau alcoólico

12 Médias dos tratamentos que a cachaça foi submetida durante o período total de envelhecimento para acidez volátil.

13 Médias dos tratamentos que a cachaça foi submetida durante o período total de envelhecimento para ésteres.

14 Médias dos tratamentos que a cachaça foi submetida durante o período total de envelhecimento para aldeídos.

15 Médias dos tratamentos que a cachaça foi submetida durante o período total de envelhecimento para furfural

16 Médias dos tratamentos que a cachaça foi submetida durante o período total de envelhecimento para álcoois superiores individualmente e para sua soma...

17 Médias dos tratamentos que a cachaça foi submetida durante o período total de envelhecimento para coeficiente de congêneres.

18 Médias dos tratamentos que a cachaça foi submetida durante o período total de envelhecimento para álcool metílico.

19 Médias dos tratamentos que a cachaça foi submetida durante o período total de envelhecimento para cobre.

20 Médias dos tratamentos que a cachaça foi submetida durante o período total de envelhecimento para extrato seco.

21 Médias dos tratamentos que a cachaça foi submetida durante o período total de envelhecimento para cor. 
22 Médias dos tratamentos que a cachaça foi submetida durante o período total 59 de envelhecimento para taninos.

23 Médias das notas atribuídas pelos provadores aos parâmetros sensoriais.......... 60

24 Valores de F da análise de variância para a variável "provadores”.................... 61 


\title{
AVALIAÇÃO FÍSICO-QUÍMICA DE CACHAÇAS COMERCIAIS E ESTUDO DA INFLUÊNCIA DA IRRADIAÇÃO SOBRE A QUALIDADE DA BEBIDA EM TONÉIS DE CARVALHO
}

\author{
Autora: MARIANA BRANCO DE MIRANDA \\ Orientador: Prof. Dr. ANDRÉ RICARDO ALCARDE
}

\section{RESUMO}

Neste trabalho foi feito um levantamento da qualidade de cachaças comerciais. As barreiras que a cachaça enfrenta, principalmente no mercado exterior, se devem à baixa qualidade e à falta de padronização da bebida. Amostras comerciais de cachaça foram analisadas segundo os padrões de identidade e qualidade estabelecidos pela legislação vigente no Brasil (análises físico-químicas e cromatográficas). Houve uma grande variação na concentração dos componentes, exceto o grau alcoólico, indicando que a cachaça brasileira apresenta uma grande variabilidade de composição química entre as marcas. Das 94 marcas analisadas, 48\% não atenderam a pelo menos um desses padrões. Outro estudo realizado foi a influência da madeira carvalho e da radiação gama no envelhecimento da cachaça. O processo de envelhecimento ou maturação da bebida proporciona uma melhora nas características sensoriais da cachaça, tornando-a de qualidade superior e de maior valor econômico. O método tradicional de maturação de bebidas é sua interação com madeiras, porém a irradiação pode acelerar este processo de envelhecimento. A cachaça e os tonéis de carvalho de 20 litros de capacidade foram submetidos à irradiação gama (150 Gy). Análises físico-químicas e cromatográficas foram realizadas periodicamente ao longo de 390 dias do período de envelhecimento da 
bebida. A irradiação da cachaça e do tonel não alterou a maioria dos componentes voláteis do coeficiente de congêneres como acidez volátil, ésteres, álcoois superiores e furfural durante os 390 dias. Há evidências, entretanto, que os parâmetros de alguns componentes como aldeídos, taninos, cor e teor de cobre são de alguma forma influenciados, resultando em aceleração parcial do processo de maturação ou envelhecimento. Ao final do período de envelhecimento, foi feita uma análise sensorial com 30 provadores não treinados. A aceleração do processo de envelhecimento foi confirmada pela avaliação sensorial, onde a cachaça e/ou tonel irradiados receberam maior indicação de aprovação em todos os parâmetros analisados (aroma, sabor e aparência). 


\section{PHYSICAL-CHEMICAL EVALUATION OF COMMERCIAL SUGAR CANE SPIRITS AND THE STUDY ABOUT THE QUALITY AND INFLUENCE OF THE IRRADIATION ON THE BEVERAGE AND ON THE OAK BARRELS}

Author: MARIANA BRANCO DE MIRANDA Adviser: Prof. Dr. ANDRÉ RICARDO ALCARDE

\section{SUMMARY}

It was performed in this study a survey on the quality of commercial sugar cane spirits. The problems that the cachaça faces, mainly in the international market, are due to its low quality and to the lack of standardization of the drink. Commercial samples of sugar cane spirits were analyzed according to the standards of the identity and quality established by the Brazilian law (physical-chemical and chromatographic analyses). There was a great variation in the concentration of the compounds, except in alcoholic content, indicating that the Brazilian sugar cane spirit presents a great variability in the chemical composition among the brands. Among the 94 analyzed brands, 48\% did not answer at least one of the standards. Another study performed was the influence of oak wood and the gamma radiation on the sugar cane spirits aging. The aging or maturation process of the drink improves the sensorial characteristics of the product, making it a qualified drink with a higher economical value. The traditional maturation method of the drinks is their interaction with the wood, but the irradiation can accelerate this aging process up. The sugar cane spirit and the oak barrels with 20 liters capacity were subjected to gamma irradiation treatments (150 Gy). Physical-chemical and chromatographic analyses were performed constantly for 390 days during the drink aging 
period. The sugar cane spirit and barrel irradiation didn't change most of volatile components of the same type coefficient such as volatile acidity, esters, superior alcohols and furfural during the 390 days. There are evidences, however, that some components parameters like aldehydes, tannin, color and copper concentration are in some way influenced, resulting in partial acceleration of the aging or maturing process. At the end of the aging period, a sensorial analysis was made using 30 non-trained people who tasted the drink. The aging process acceleration was confirmed by the sensorial evaluation, where the sugar cane spirit and/or barrel irradiated received higher approval indication in respect of all parameters analyzed (scent, flavor, and appearance). 


\section{INTRODUÇÃO}

A cachaça, bebida genuinamente nacional produzida praticamente em todo o país, segundo Drinks International (1994) era a bebida destilada mais consumida no mundo. Entretanto, ela passou a ser a terceira bebida destilada mais consumida no mundo e a primeira no Brasil, segundo Associação Brasileira de Bebidas (ABRABE, 2005) ${ }^{1}$.

O envelhecimento em tonéis de madeira é uma das etapas mais importantes do processo de agregação de valor e qualidade sensorial da cachaça. A madeira tradicionalmente utilizada na manufatura dos tonéis para o envelhecimento de bebidas destiladas é o carvalho. As reações que ocorrem durante o envelhecimento favorecem a formação de compostos que influenciam na cor, odor e sabor da bebida, tornando-a mais agradável.

Nos últimos anos, cachaça de cana está sendo consumida cada vez mais por todas as classes da população no Brasil, tornando-se uma bebida sofisticada. Segundo Moraes (2001), em alguns países da Europa como Alemanha, Itália e França, Estados Unidos, e Japão, a cachaça é consumida principalmente sob a forma de coquetel, com destaque a “caipirinha”.

Apesar da tradição e importância desta bebida, a cadeia produtiva da cachaça no país não é tecnologicamente homogênea, havendo uma busca no desenvolvimento de tecnologias para aprimorar e controlar a qualidade e a padronização da bebida. O aprimoramento da qualidade e da padronização da cachaça é essencial para que a bebida atenda aos padrões internacionais e seja aceita pelo mercado exterior, propiciando condições de abertura e manutenção de um firme mercado de exportação,

\footnotetext{
${ }^{1}$ Associação Brasileira de Bebidas. Comunicação Pessoal, 2005.
} 
assim como aumentar sua aceitação no mercado interno pelas classes de maior poder aquisitivo, que estão dispostas a pagar mais caro por uma bebida desde que esta seja de qualidade elevada.

Neste trabalho foi feito um levantamento de marcas comerciais de cachaça quanto à conformidade com os padrões de identidade e qualidade previstos pela legislação vigente através de análises físico-químicas e cromatográficas. Outro estudo foi a influência da irradiação gama sobre a qualidade (físico-química e sensorial) da cachaça em tonéis de carvalho durante um período de maturação. 


\section{REVISÃO DE LITERATURA}

\subsection{Cachaça}

A produção de cachaça no Brasil teve início no período colonial após a introdução da cana na Capitania de São Vicente e a montagem do primeiro engenho de açúcar. Até o fim da $2^{\mathrm{a}}$ guerra mundial (1939-1945), a cachaça era produzida em grande número de fábricas de pequena capacidade, atrasadas tecnicamente quando comparadas com as de hoje.

As características de qualidade como sabor, aroma e cor eram os mais variados e algumas cachaças de destacavam pelas propriedades organolépticas peculiares, resultado de técnicas de fermentação, destilação e variedade da madeira de construção dos tonéis. O aumento da produção ocorreu com o fim da guerra quando surgiram as destilarias de maior porte e com elas a necessidade de conhecimentos técnicos e científicos, desde a cultura da cana ao engarrafamento da cachaça (Lima, 1992).

A produção de cachaça é de 1,3 bilhões de litros por ano e existem atualmente mais de 5 mil marcas registradas e cerca de 30 mil produtores em todo o país (ABRABE, 2005). Segundo Moraes (2001), 70\% da cachaça é consumida pura no Brasil. As exportações representam apenas em torno de 1\% da produção total (López, 2003), e os principais países importadores são Alemanha, Portugal e Estados Unidos, respectivamente. Em 2003 a exportação foi de 5,2 milhões de litros de cachaça e em 2004 aumentou para 10,2 milhões de litros (Brasil, 2005a).

O mercado está cada vez mais exigente, considerando que começa a aparecer no país um consumidor novo para o produto, aquele que antes não tomava cachaça. Os produtores começaram a se preocupar em agregar mais valor à bebida, tanto em 
controle de qualidade, como embalagens mais finas, com o objetivo de se inserir nos melhores pontos de consumo do país ao lado de outras bebidas destiladas já consagradas.

\subsection{Caracterização da aguardente e da cachaça}

Aguardente de cana possui uma graduação alcoólica de 38 a 54\% em volume, a $20^{\circ} \mathrm{C}$, obtida de destilado alcoólico simples de cana-de-açúcar (Saccharum officinarum L.) ou pela destilação do mosto fermentado de cana-de-açúcar, podendo ser adicionada de açúcares até $6 \mathrm{~g} \mathrm{~L}^{-1}$. A aguardente de cana envelhecida refere-se à bebida que contiver, no mínimo, 50\% de aguardente de cana envelhecida em recipiente de madeira apropriado, com capacidade máxima de 700 litros, por um período não inferior a um ano (Brasil, 1997a).

Aguardente de cana premium refere-se à bebida que contiver $100 \%$ de aguardente de cana envelhecida em recipiente de madeira apropriado, com capacidade máxima de 700 litros, por um período não inferior a um ano. Aguardente de cana extra premium refere-se à bebida que contiver 100\% de aguardente de cana envelhecida em recipiente de madeira apropriado, com capacidade máxima de 700 litros, por um período não inferior a três anos (Brasil, 2005b).

Cachaça é a denominação típica e exclusiva da aguardente de cana produzida no Brasil (Brasil, 2001), com graduação alcoólica de 38 a $48 \%$ em volume, a $20^{\circ} \mathrm{C}$ e com características sensoriais peculiares, podendo ser adicionada de açúcares até $6 \mathrm{~g} \mathrm{~L}^{-1}$ (Brasil, 2002). Cachaça envelhecida, cachaça premium e cachaça extra premium seguem as mesmas definições descritas para aguardentes dos mesmos tipos. Aguardente de cana e cachaça envelhecida, aguardente de cana e cachaça premium e aguardente de cana e cachaça extra premium podem ser adicionadas de caramelo para correção de cor (Brasil, 2005b).

A aguardente de cana ou caninha está submetida à Legislação Nacional (Brasil, 1974), de responsabilidade do Ministério da Agricultura e Abastecimento (MAAb), atual MAPA (Ministério da Agricultura, Pecuária e Abastecimento), que estabelece os 
denominados padrões de identidade e de qualidade aos quais a bebida deve atender (Tabela 1).

Tabela 1. Características físicas e químicas para a aguardente de cana-de-açúcar, estabelecidas pela legislação brasileira (Brasil, 1974)

\begin{tabular}{|c|c|c|c|}
\hline \multirow[b]{2}{*}{ Componente } & \multirow[b]{2}{*}{ Unidade } & \multicolumn{2}{|c|}{ Limite } \\
\hline & & mínimo & Máximo \\
\hline Graduação alcoólica & $\begin{array}{c}\text { \% em volume de álcool } \\
\text { etílico a } 20^{\circ} \mathrm{C}\end{array}$ & 38 & 54 \\
\hline $\begin{array}{l}\text { Sacarose, em açúcar refinado, } \\
\text { cristal, invertido ou glicose }\end{array}$ & $\mathrm{g} / \mathrm{L}$ & 6,0 & 30,0 \\
\hline Acidez volátil, em ácido acético & mg/100 mL álcool anidro & - & 150 \\
\hline Ésteres, em acetato de etila & mg/100 mL álcool anidro & - & 200 \\
\hline Aldeídos, em aldeído acético & mg/100 mL álcool anidro & - & 30 \\
\hline Furfural & mg/100 mL álcool anidro & - & 5 \\
\hline Álcoois superiores & mg/100 mL álcool anidro & - & 300 \\
\hline Congêneres * & mg/100 mL álcool anidro & 200 & 650 \\
\hline Álcool metílico & mg/100 mL álcool anidro & - & 200 \\
\hline Cobre & $\mathrm{mg} / \mathrm{L}$ & - & 5,0 \\
\hline Extrato seco & $\mathrm{g} / \mathrm{L}$ & - & $6,0^{* *}$ \\
\hline Partículas em suspensão (resíduo & & & \\
\hline sólido de qualquer espécie) & - & ausentes & ausentes \\
\hline
\end{tabular}

De acordo com a Instrução Normativa $\mathrm{n}^{0} 13$ de 30 de junho de 2005, a concentração máxima de álcoois superiores permitida é $360 \mathrm{mg} 100 \mathrm{~mL}^{-1}$ de álcool anidro, e não mais $300 \mathrm{mg} 100 \mathrm{~mL}^{-1}$, favorecendo a conformidade de cachaças anteriormente consideradas fora dos padrões legais do MAPA. 
Alem disso, foram definidas quantidades máximas permitidas de alguns contaminantes anteriormente não mencionados como carbamato de etila (150 $\left.\mu \mathrm{g} \mathrm{L}^{-1}\right)$, acroleína (5 mg $100 \mathrm{~mL}^{-1}$ de álcool anidro), álcool sec-butílico (10 mg $100 \mathrm{~mL}^{-1}$ de álcool anidro), álcool n-butílico (3 mg $100 \mathrm{~mL}^{-1}$ de álcool anidro), chumbo (200 $\mu \mathrm{g} \mathrm{L}{ }^{-1}$ ) e arsênio (100 $\left.\mu \mathrm{g} \mathrm{L}^{-1}\right)$. O prazo máximo para adequação e controle dos contaminantes da cachaça, com início na data da publicação da Instrução Normativa $n^{0} 13$, é de 3 anos, com exceção do carbamato de etila que é 5 anos, portanto não foram incluídos na avaliação neste trabalho.

O carbamato de etila ou uretana é um composto considerado potencialmente carcinogênico. O Canadá, primeiro país com legislação específica sobre o assunto, foi um referencial para os Estados Unidos e a Comunidade Européia, que seguiram o teor máximo deste contaminante estabelecido por aquele país para bebidas destiladas (150 $\mu \mathrm{g}$ $\mathrm{L}^{-1}$ ). A obrigatoriedade da detecção e controle do carbamato de etila na cachaça torna-se de grande importância, pois além dos aspectos ligados à saúde pública, sua presença em concentrações superiores a $150 \mu \mathrm{g} \mathrm{L} \mathrm{L}^{-1}$ constitui também uma barreira para exportações para Europa e América do Norte (Andrade-Sobrinho et al, 2002).

O cobre é um dos metais indesejáveis na cachaça, e seu limite permitido permanece $5 \mathrm{mg} \mathrm{L}^{-1}$ (Brasil, 2005). Sua presença na bebida provém do material tradicionalmente utilizado na construção dos alambiques. A legislação de alguns países do hemisfério norte estabelece um limite inferior a $2 \mathrm{mg} \mathrm{L^{-1 }}$ de cobre $\left(\mathrm{Cu}^{2+}\right)$ nos destilados alcoólicos (Brasil, 1974), dificultando a exportação da cachaça para esses países. Atualmente, a cachaça deve seguir os padrões de identidade e qualidade descritos na tabela 2. 
Tabela 2. Características físicas e químicas para a aguardente de cana-de-açúcar e cachaça, estabelecidas pela legislação brasileira (Brasil, 2005b)

\begin{tabular}{|c|c|c|c|}
\hline \multirow[b]{2}{*}{ Componente } & \multirow[b]{2}{*}{ Unidade } & \multicolumn{2}{|c|}{ Limite } \\
\hline & & mínimo & máximo \\
\hline Graduação alcoólica de aguardente & $\begin{array}{l}\text { \% em volume de álcool } \\
\text { etílico a } 20^{\circ} \mathrm{C}\end{array}$ & 38 & 54 \\
\hline Graduação alcoólica de cachaça & $\begin{array}{l}\text { \% em volume de álcool } \\
\text { etílico a } 20^{\circ} \mathrm{C}\end{array}$ & 38 & 48 \\
\hline $\begin{array}{l}\text { Sacarose, em açúcar refinado, } \\
\text { cristal, invertido ou glicose }\end{array}$ & $\mathrm{g} / \mathrm{L}$ & 6,0 & 30,0 \\
\hline Acidez volátil, em ácido acético & mg/100 mL álcool anidro & - & 150 \\
\hline Ésteres, em acetato de etila & mg/100 mL álcool anidro & - & 200 \\
\hline Aldeídos, em aldeído acético & mg/100 mL álcool anidro & - & 30 \\
\hline Furfural & mg/100 mL álcool anidro & - & 5 \\
\hline Álcoois superiores * & mg/100 mL álcool anidro & - & 360 \\
\hline Congêneres ** & mg/100 mL álcool anidro & 200 & 650 \\
\hline Álcool metílico & mg/100 mL álcool anidro & - & 200 \\
\hline Cobre & $\mathrm{mg} / \mathrm{L}$ & - & 5,0 \\
\hline Extrato seco & $g / L$ & - & $6,0^{* * *}$ \\
\hline Partículas em suspensão (resíduo & & & \\
\hline sólido de qualquer espécie) & - & ausentes & ausentes \\
\hline
\end{tabular}

Esses padrões e seus respectivos limites têm a finalidade de moderar a influência de cada um desses componentes na proteção à saúde pública e na qualidade da bebida, não significando, entretanto, que a cachaça que ali se enquadre possa ser considerada um produto de qualidade sensorial superior. 


\subsection{Processo de produção}

\subsubsection{Matéria-prima}

A cana-de-açúcar (Saccharum spp.) é cultivada em todo o mundo para produção de açúcar, álcool ou cachaça, sendo as principais espécies originárias da Oceania (Nova Guiné) e Ásia (Índia e China). O Brasil, que tem uma área plantada com cana-de-açúcar de aproximadamente 5 milhões de hectares, é o maior produtor mundial desse vegetal, sendo São Paulo o maior estado produtor (Andrade, 2001). A produtividade média do país gira em torno de $71,1 \mathrm{t} \mathrm{ha}^{-1}$ (FNP, 2004). Além da produtividade, fatores como planejamento agrícola, controle de pragas e doenças, maturação, colheita, carregamento e transporte são também responsáveis pela melhoria da qualidade da matéria prima recebida pelas indústrias (Yokoya, 1995).

Segundo Lima (2001), quanto mais madura a cana, mais o caldo será rico em açúcares. Nas canas maduras o teor de açúcares redutores é de 1\% e o de sacarose em torno de $14 \%$. As canas não devem ser colhidas com menos de $14 \%$ de açúcares $\left(18^{\circ}\right.$ Brix).

A safra de cana-de-açúcar de 2004/2005 foi de 387,2 milhões de toneladas, e a estimativa para 2005/2006 é de 398,8 milhões de toneladas, ou seja, um aumento de 2,9\%. A previsão da produção da safra de 2013/2014 é de 547 milhões de toneladas, permanecendo concentrada na região Centro-Sul (FNP, 2004).

\subsubsection{Fermentação e destilação}

Após a colheita da cana-de-açúcar, faz-se a extração do seu caldo através de moendas. O caldo é constituído de 65-75\% de água, 11-18\% de açúcares (sacarose, glicose e frutose), pequenas quantidades de substâncias nitrogenadas, ceras, lipídeos, pectinas e materiais corantes (clorofila, antocianinas e compostos polifenólicos) e sais minerais. Seu pH é ácido (4,8-6,0), favorecendo o desenvolvimento de microrganismos (Schwan \& Castro, 2001). Na microflora do caldo são encontradas leveduras dos gêneros 
Candida, Criptococcus, Hansenula, Saccharomyces e Torulopsis, e bactérias mais freqüentes são Leuconostoc dextranicum e L. mesenteroides. O caldo é então peneirado e adicionado de fermento, tornando-se o mosto. Entre as leveduras, a espécie usada é Saccharomyces cerevisiae. (Lima, 2001).

A levedura, nas condições anaeróbicas, metaboliza os açúcares do mosto transformando-os em álcool etílico, gás carbônico e pequenas quantidades de glicerol, ácido succínico, entre outros compostos. Se houver contaminação bacteriana, os açúcares podem resultar em ácidos carboxílicos (acético, fórmico, butírico e láctico), aldeídos e ésteres (Yokoya, 1995). Os produtos da fermentação seguem dois caminhos: sedimentação do fermento ou centrifugação. Em ambas as operações obtêm-se fermento (sedimentado e recuperado, respectivamente) que passa por tratamento e retorna para a fermentação, e vinho (sobrenadante e centrifugado, respectivamente) que segue para uma única dorna volante.

A etapa seguinte na produção de cachaça é a destilação do vinho que consiste em separar e selecionar os produtos de acordo com as temperaturas de ebulição ou de mudança de fase do componente (Sales, 2001). O vinho possui composição complexa apresentando componentes sólidos (açúcares não fermentados, sais minerais, substâncias nitrogenadas, pectina, células de levedura e bactéria, bagacilho e argila), líquidos (água e etanol, representando 99\% do total) e gasosos (principalmente gás carbônico). Com a destilação do vinho obtém-se o flegma (frações “cabeça”, “coração” e “cauda”) e a vinhaça, também conhecida como vinhoto e restilo (Yokoya, 1995). Por meio da destilação, o vinho proveniente da fermentação alcoólica com 5 a 8\% em volume de álcool etílico, deverá produzir 15 a 17\% do volume do vinho destilado em aguardente, contendo de 38 a 54\% de volume em álcool. O flegma (aguardente) é armazenado em tanques (aço carbono, aço inox ou madeira) (Sales, 2001). A vinhaça é utilizada como fertilizante, sendo aplicada na própria cana que lhe deu origem, em função da proximidade dessa cultura com a indústria (Evangelista, 2001). Todas as etapas descritas acima são de responsabilidade do produtor, que comercializa a aguardente ou cachaça para uma outra unidade que padroniza, engarrafa e disponibiliza a bebida ao consumidor. A figura 1 traz de maneira simplificada todo o processo de produção descrito acima. 


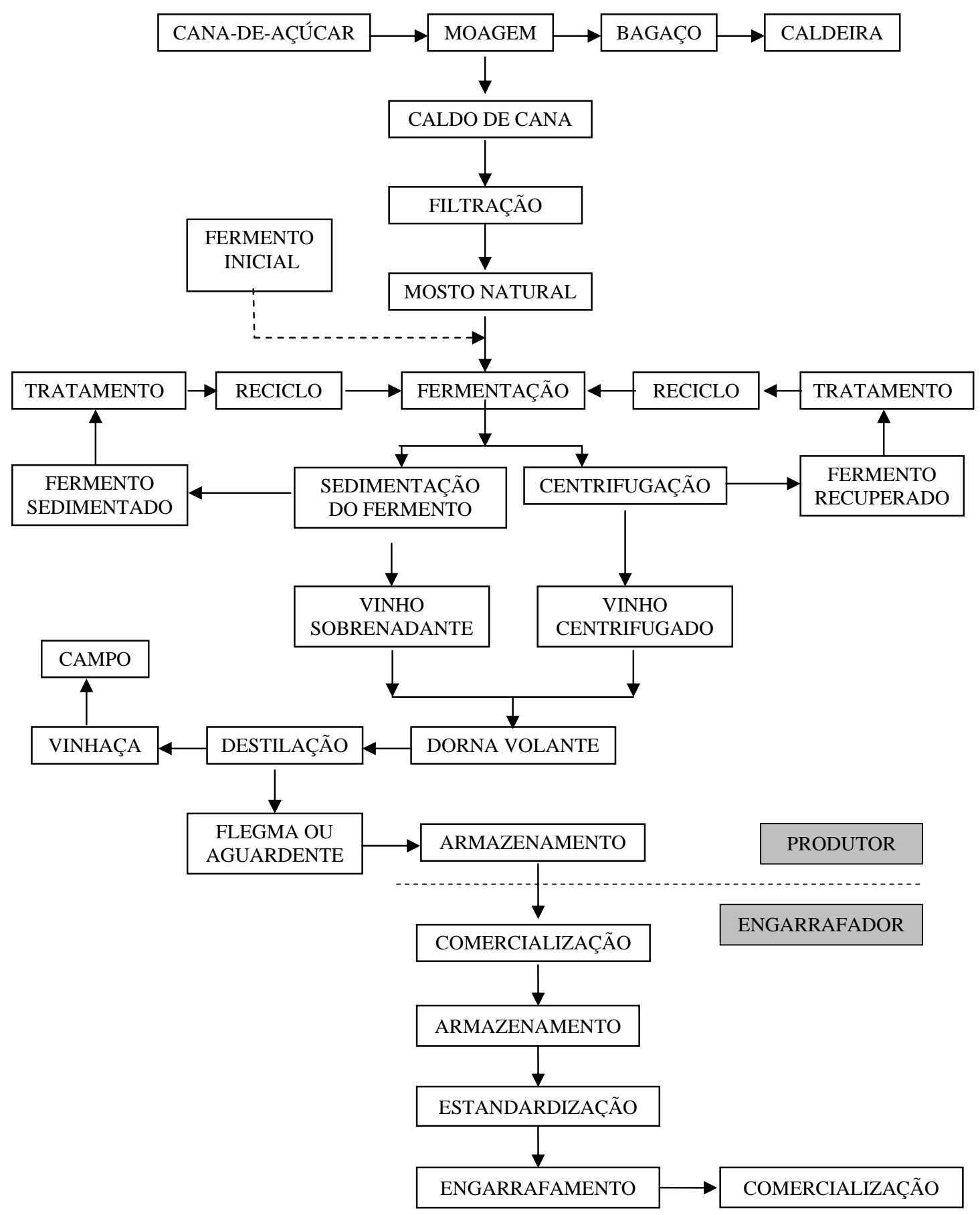

Figura 1- Fluxograma de produção da cachaça 


\subsubsection{Componentes secundários}

Os produtos secundários são todas as substâncias formadas durante a fermentação alcoólica, excetuando os produtos principais (álcool etílico e gás carbônico). Eles são encontrados em pequenas quantidades e muitas vezes são difíceis de serem determinados ou quantificados (Yokoya, 1995). A natureza e proporção desses compostos são determinadas, em diferentes níveis, pelas características da matéria-prima, da fermentação, da destilação e do envelhecimento. Os principais compostos secundários formados durante a fermentação alcoólica pertencem às classes funcionais dos ácidos, ésteres, aldeídos e álcoois, e em proporções menores formam-se também cetonas, compostos fenólicos aminas e mercaptanas (Maia, 1994).

O ácido acético é um co-produto normal da fermentação alcoólica. A alta acidez em cachaça pode ser atribuída à contaminação da cana ou do próprio mosto por bactérias acéticas, fazendo com que parte do substrato sofra fermentação acética, elevando a acidez e diminuindo o rendimento da produção de etanol (Cardoso, 2001). A aeração do mosto durante esta etapa também pode aumentar a conversão do açúcar em ácido acético, ainda que não haja contaminação do mosto por essas bactérias (Maia, 1994).

Durante a fermentação alcoólica, uma parte do etanol reage com o ácido acético, formando acetato de etila (Cardoso, 2001; Maia, 1994; Yokoya, 1995). Da mesma forma, outros álcoois reagem, em parte, com o ácido acético resultando em outros ésteres. Reações de esterificação ocorrem também durante o envelhecimento da cachaça, mas em uma velocidade muito menor. Segundo Maia (1994), os ésteres favorecem o aroma da bebida, e cada éster tem um aroma peculiar; o acetato de etila possui aroma frutado que em grandes quantidades confere à cachaça um sabor indesejável e enjoativo.

Os aldeídos com até oito átomos de carbono tem aromas penetrantes e enjoativos, considerados indesejáveis em bebidas destiladas. Os aldeídos maiores, com mais de dez átomos de carbono, apresentam aroma agradável. O principal aldeído associado à fermentação alcoólica é o acetaldeído (Maia, 1994). Em fermentações normais este composto aparece no mosto durante as primeiras horas e diminui podendo até desaparecer no estágio final da fermentação. Os aldeídos podem ter origem no resultado 
da ação das leveduras durante estágios preliminares do processo da fermentação, principalmente o acetaldeído, que tende a desaparecer no final pela oxidação a ácido acético (Cardoso 2001; Maia, 1994).

O furfural e o hidroximetilfurfural não são formados durante a fermentação. Esses aldeídos podem aparecer no próprio caldo da cana, quando sua colheita é precedida da queima da folhagem, acarretando desidratação parcial de uma pequena fração de açúcares (pentoses e hexoses) livres no caldo ou presentes no bagaço (Maia, 1994).

Álcoois superiores, com três a cinco átomos de carbono, apresentam odores característicos (“bouquet”), tradicionalmente associados com bebidas destiladas. Acima disso, os álcoois tornam-se oleosos e alguns lembram fortemente o aroma de flores. Os álcoois de 4 e 5 átomos de carbono (óleo fúsel) são formados pela degradação do açúcar dentro das leveduras, e em parte pela degradação de aminoácidos (Maia, 1994) e em teor elevado desvaloriza a cachaça (Yokoya, 1995). Do ponto de vista quantitativo, a formação de álcoois superiores depende acentuadamente da cepa empregada, assim como da ocorrência de microrganismos contaminantes. A formação desses álcoois é maior quando a fermentação é mais demorada devido à atividade fraca do fermento (Maia, 1994).

O álcool metílico é um álcool indesejável na cachaça, originando-se da degradação de pectina, um polissacarídeo da cana-de-açúcar, presente em quantidades muito pequenas (Maia, 1994). A intoxicação por álcool metílico causa alguns sintomas como cefaléia, vertigem, vômitos e dores diversas. Dependendo do organismo a dose fatal varia de 10 a $100 \mathrm{~mL}$ e a ingestão de $15 \mathrm{~mL}$ é suficiente para causar cegueira (Cardoso, 2001).

Entretanto, a legislação nacional (Brasil, 2002) traz como limite máximo 200 mg de álcool metílico por $100 \mathrm{~mL}$ de álcool anidro ou 0,25 mL de álcool metílico por 100 $\mathrm{mL}$ de álcool anidro, um valor pequeno mas muito acima dos valores encontrados usualmente em cachaças. Apenas para citar, aguardente de frutas possui um limite máximo de 700 mg de álcool metílico por 100 mL de álcoo anidro (Brasil, 2002), justamente por derivar de frutas com alto teor de matérias pécticas. 


\subsubsection{Qualidade da cachaça}

A cachaça requer conhecimentos científicos e tecnológicos apurados, competência, sensibilidade e dedicação.Os aspectos gerais do controle de qualidade da cachaça exigem realização de análises físico-químicas periódicas (Cardoso, 2001). A qualidade da bebida está relacionada a suas propriedades organolépticas, tais como cor, sabor e aroma, que, por sua vez, dependem da qualidade da matéria-prima, do mosto e do fermento utilizados, das condições e do tempo de fermentação, do sistema de destilação, do material de fabricação dos equipamentos e dos processos de envelhecimento, padronização e de engarrafamento da bebida (Vargas \& Glória, 1995).

A existência do manual de procedimentos no controle da produção de bebidas baseadas nos princípios do sistema de análise de perigos e pontos críticos de controle (APPCC) proposto pelo MAPA (Brasil, 1997b), não é suficiente para atuação preventiva durante todo o processo de elaboração da cachaça em substituição da tradicional conferência do produto acabado. Medidas de prevenção, monitoramento contínuo e ações corretivas durante a produção são obrigatórias na indústria de alimentos, garantindo o fornecimento de produtos mais seguros ao consumidor e atendendo às exigências do mercado globalizado. No entanto, essas práticas não são uma realidade na maioria das unidades produtoras de cachaça, talvez pela adesão ao sistema APPCC ser espontânea.

A produção industrial da cachaça, que representa cerca de 95\% do total produzido, cabendo os outros 5\% à produção artesanal, produz um destilado alcoólico bruto, apresentando uma concentração em álcool da ordem de $47,5 \%$ em volume a $20^{\circ} \mathrm{C}$. Posteriormente, esse destilado é comercializado às estandardizadoras, unidades industriais que realizam a homogeneização e padronização da bebida através da mistura entre os destilados de diferentes procedências e ajuste do teor alcoólico da bebida. Em seguida a cachaça é filtrada e, finalmente, envasada e comercializada (Novaes, 1996).

Apesar dos obstáculos citados pelos produtores como entraves à exportação de cachaça serem a taxação nos mercados americano e europeu, a falta de marketing e de rede de distribuição adequada (Franco, 2002), na verdade um dos pontos mais delicados no processo de aceitação da cachaça no mercado exterior é a baixa qualidade e 
padronização da bebida produzida, a qual muitas vezes não está adequada aos padrões internacionais de qualidade exigidos por este mercado para bebidas destiladas.

Apesar do alto volume de cachaça produzido pelo Brasil, a negligência na observação de padrões de identidade exigidos pelo MAPA e a falta de controle da qualidade da bebida têm sido as principais barreiras a um maior avanço da cachaça no mercado externo. Pelas mesmas razões, observa-se no mercado interno grande variação na qualidade das cachaças.

\subsubsection{Envelhecimento}

As bebidas alcoólicas apresentam uma ampla variação de "flavor", sendo que os compostos voláteis responsáveis pelo odor e sabor dessas bebidas são álcoois, aldeídos, ácidos orgânicos e ésteres (Packowski, 1978), denominados congêneres (Brasil, 1997a).

A qualidade de uma bebida é julgada pelo consumidor através da cor, odor e sabor, ou seja, pelas suas propriedades sensoriais. O envelhecimento da cachaça em tonéis de madeira promove diminuição significativa do sabor alcoólico e da agressividade da bebida, com simultâneo aumento da doçura e do sabor de madeira, proporcionando uma efetiva melhora sensorial do produto (Cardello \& Faria, 1999).

A mudança do aroma e do sabor da bebida maturada deve-se a alterações na composição e na concentração dos seus compostos, as quais são causadas por extração dos compostos da madeira; quebra de suas macromoléculas e extração dos seus produtos; reações entre os compostos do destilado e da madeira; reação entre os próprios extrativos da madeira; reação entre os próprios componentes do destilado; e evaporação dos compostos voláteis. Dentre estas, destacam-se em importância as três primeiras (Mosedale \& Puech, 1998).

Algumas substâncias podem ser consideradas referências no processo de envelhecimento. Durante a maturação de bebidas destiladas, normalmente ocorre uma diminuição do pH e das concentrações de álcool metílico e de álcool etílico, enquanto que há um aumento da acidez, da cor e das concentrações de acetato de etila, de aldeído 
acético, de acetona e dos compostos fenólicos (taninos) (Cardello \& Faria, 1997; Puech, 1983; Souza \& Del Mastro, 2000).

Outras bebidas recém destiladas, como, por exemplo, o whisky, também possuem sabor picante e odor pungente e desagradável, sendo o processo de envelhecimento ou maturação em tonéis de carvalho, por determinado período, necessário para tornar o seu aroma e sabor agradáveis (Clyne et al., 1993). Os principais compostos extraídos da madeira do tonel pelos destilados são: óleos voláteis, substâncias tânicas, açúcares, glicerol, ácidos orgânicos não voláteis, esteróides, os quais modificam o aroma, o sabor e a coloração da bebida (Nishimura \& Matsuyama, 1989).

O cerne das madeiras é constituído de compostos da parede celular e compostos extrativos. Os da parede celular são celulose, hemicelulose e lignina, e os extrativos são compostos fenólicos (taninos), ácidos graxos e constituintes menores (Mosedale \& Puech, 1998).

Na maturação, a madeira sofre degradação pela ação do álcool e da água. Ocorre hidrólise da hemicelulose e da lignina, sendo que os produtos dessa hidrólise passam para o destilado (Shreve \& Brink, 1980). A celulose parece não sofrer degradação pelo álcool. Porém, o tratamento do barril com fogo pode causar termólise da celulose e da hemicelulose, que se decompõem em açúcares, os quais, por sua vez, podem ser desidratados e degradados pela alta temperatura, originando os furanos e piranos presentes nos destilados envelhecidos (Sefton et al., 1990).

Durante a maturação do destilado, a hemicelulose, que é constituída de xilose e outros açúcares, é ligeiramente degradada em pentoses e hexoses, resultando no aumento na concentração de açúcares na bebida envelhecida (Puech, 1988).

A lignina, que é formada por monômeros aromáticos, tem estreita relação com o desenvolvimento de aroma e sabor nos destilados envelhecidos porque libera para a bebida aldeídos aromáticos durante o período de maturação. Porém, apenas pequena fração da lignina é solúvel e, conseqüentemente, extraída durante o período de maturação (Singleton, 1995).

Os taninos, que são um dos constituintes menores da madeira, são responsáveis pelo progressivo escurecimento da cor do destilado com o envelhecimento (Singleton, 
1995). A concentração de furfural, composto oriundo das pentoses da madeira, tende a aumentar com a maturação do destilado (Egorov \& Rodopulo, 1994).

Como já citado anteriormente, a oxidação do álcool etílico e dos aldeídos durante a maturação dos destilados produz respectivamente, aldeídos (ex. acetaldeído) e ácidos (ex. ácido acético). A esterificação dos álcoois e ácidos produz ésteres, como acetato de etila, responsáveis pelo odor agradável das bebidas envelhecidas (Litchev, 1989). Por isso, as bebidas maturadas tendem a apresentar maiores concentrações de ésteres e aldeídos.

Quanto maior o grau alcoólico do destilado a ser envelhecido, mais lenta foi a extração de taninos, de ácidos voláteis e de açúcares, pois a degradação hidrolítica da madeira requer água (Reazin, 1981).

O processo de envelhecimento de bebidas destiladas, geralmente realizadas em tonéis de madeira, é etapa obrigatória nos Estados Unidos e Inglaterra (Boza \& Oetterer, 1999). No Brasil, para cachaça esta etapa é optativa, não sendo realizada sistematicamente devido ao tempo requerido pelo processo e aos custos introduzidos pelo armazenamento da bebida em grandes tonéis por alguns anos. Este procedimento melhora a qualidade sensorial da bebida, tornando-a mais suave, com sabor e aroma mais agradável e com coloração amarelada mais atraente, embora a legislação não o estabeleça como envelhecimento.

\subsubsection{Técnicas modernas de envelhecimento de bebidas}

O carvalho é a principal madeira utilizada para o envelhecimento de bebidas. O carvalho branco americano (Quercus alba) e o carvalho europeu (Quercus robur e Quercus petraea) são tradicionalmente usados na manufatura de barris para envelhecimento de bebidas devido às suas propriedades de dureza, flexibilidade e impermeabilidade à água, bem como pela liberação de extrativos necessários à maturação de bebidas alcoólicas, conferindo cor e aroma suave à bebida.

Como o carvalho não é uma árvore nativa do Brasil, os tonéis fabricados com essa madeira são provenientes principalmente dos Estados Unidos e Escócia. A 
legislação dos EUA impõe que o whisky bourbon seja envelhecido em tonéis novos de carvalho, enquanto que a legislação escocesa não tem essa restrição. Desta forma muitos tonéis de carvalho que chegam aqui já foram utilizados nesses dois países (Boscolo et al., 1995).

O nosso país possui quantidade infindável de espécies de madeira com viabilidade de uso e que não podem ser desprezadas por apresentarem uma ou outra característica que as tornem inutilizáveis. Todas as madeiras podem ser utilizadas para que se encontre uma composição de extratos capaz de promover qualidade de envelhecida à cachaça (Campos \& Casimiro, 2000).

Devido ao alto custo e às inúmeras reutilizações dos tonéis de carvalho antes de serem utilizados na maturação de cachaça, um estudo sobre o efeito de diferentes tipos de madeiras brasileiras (amburama, bálsamo, jequitibá, ipê e jatobá) na composição química dessa bebida mostrou que a amburama foi a que mais se aproximou dos valores obtidos com tonéis de carvalho (Dias, 1997).

Mosedale \& Puech (1998) citam que o uso das radiações ionizantes pode ser uma nova técnica para o tratamento dos tonéis e das madeiras para envelhecimento de bebidas, visando aumentar a taxa de extração e de reações entre os compostos. A irradiação da madeira parece permitir uma extração mais rápida dos seus compostos (Souza \& Del Mastro, 2000). Segundo Urbain (1986) doses entre 100 e 150 Gy produziram conhaques com sabor e aroma equivalentes aos obtidos com três anos de envelhecimento natural. Estudos realizados no Centro de Energia Nuclear na Agricultura (CENA/USP) com irradiação de cachaça com doses de 50, 100, 150, 200, 250 e 300 Gy, mostraram que as cachaças irradiadas com as doses de 150 e 200 Gy obtiveram maior aceitação sensorial pelos provadores (Walder et al., 2004). 


\section{MATERIAL E MÉTODOS}

\subsection{Levantamento da qualidade das cachaças}

Amostras de cachaças comerciais foram analisadas segundo os padrões de identidade e qualidade em vigor, que se encontram na tabela 2. A relação em ordem alfabética das marcas analisadas é: “Água Santa” (artesanal); “Altarugio” (artesanal); “Arte de Minas”; “Barra Grande”; "Bertozzi”; “Big” (adoçada); "Biquinha”; "Bom Sucesso de Minas”; “Branquinha da Moenda”; “Branquinha de Piracicaba” (adoçada); “Cachaça 51” (adoçada); “Cachaça da Roça” (adoçada); “Cachaça de São Francisco”; “Caninha 21 Pirassununga” (adoçada); “Caninha 3 Fazendas” (adoçada); “Caninha Casteluche”; “Caninha Chapéu de Palha Ouro” (adoçada e envelhecida); “Caninha da Roça” (adoçada); “Caninha Itiquira”; “Caninha Janaína” (adoçada); “Caninha Oncinha” (adoçada); “Caninha Serra Bonita” (adoçada); “Caninha Tatuzinho” (adoçada); “Cavalinho” (adoçada); “Chão Valente”; “Coluninha”; “Da Diretoria” (envelhecida); “Decência”; "Destilaria 36” (bidestilada e envelhecida em tonel de carvalho); “Do Barão” (envelhecida em tonéis de carvalho); "Do Barão” (envelhecida em tonéis de jequitibá); “Do Barril” (adoçada); “Dona Bica”; “Engenho Celeste”; “Engenho Central”; "Engenho Central” (envelhecida); "Engenho da Vertente” (envelhecida em tonel de carvalho); “Engenho de Minas” (artesanal e envelhecida em tonel de madeira); "Espírito de Minas” (envelhecida em tonel de carvalho); "Evolução” (envelhecida em tonel de carvalho); “Feitiço Mineiro”; “Germana”; “Holy”; “Itaguaçú” (bidestilada); “Jaguary”; “Jamel”; "Jequity Cristal”; "JG Ouro”; “JG Prata”; "Maravilha do Século XX”; "Matraga” (Série Ouro / orgânica e bidestilada); "Matraga” (Série Prata / orgânica e 
“Matraga” (bidestilada); “Mel de Minas”; "Mistura Fina” (armazenada em tonéis de carvalho); "Mistura Fina” (envelhecida em tonéis de carvalho); "Mulher Rendeira”; "Nega Fulo”; "Padilha” (artesanal); "Pirassununga 51” (adoçada); "Pitú Gold” (envelhecida); “Pitú” (adoçada); "Pompolo” (adoçada); "Pompolo” (adoçada e envelhecida); “Puma” (adoçada); “Rosa”; “Sabor Brasil” (artesanal e envelhecida em tonel de carvalho); “Sapucaia Florida” (superior); “Sapucaia Velha” (reserva da família); “Sapucaia Velha” (tradicional); “Sapupara Ouro” (envelhecida); “Sapupara Prata”; “Senzala” (adoçada); “Sinhá do Engenho” (bidestilada); “Supimpa”; “Terra de Santa Cruz”; “Todas”; “Uma”; “Universitária” (adoçada); “Urucuiana”; “Urucuiana” (envelhecida); "Vale Verde" (envelhecida em tonel de carvalho); "Vat 45” (adoçada e envelhecida); "Velho Alambique" (artesanal e envelhecida); "Velho Alambique" (artesanal não envelhecida); "Velho Alambique" (bidestilada e envelhecida); "Velho Alambique” (branca); "Velho Barreiro Gold” (adoçada e envelhecida); "Velho Barreiro” (adoçada e envelhecida em tonel de carvalho); "Villa Velha” (adoçada); "Vip”; "Ypióca Ouro" (envelhecida); "Ypióca Prata” (adoçada); "Ypióca” (reserva especial e envelhecida); “88” (adoçada).

\subsubsection{Análises físico-químicas}

Todas as análises foram feitas em duplicata. As análises de grau alcoólico, acidez volátil, extrato seco e furfural seguiram as metodologias oficiais descritas em Brasil (1986). A acidez fixa foi obtida pela diferença entre a acidez total e a volátil. A determinação de cobre seguiu a metodologia do Instituto Adolfo Lutz (Pregnolato \& Pregnolato, 1985). A determinação de açúcares redutores totais foi feita através do método Lane-Eynon (Yokoya, 1995).

\subsubsection{Análises cromatográficas}

As análises cromatográficas foram: aldeídos, ésteres, álcoois superiores: (npropílico, álcool isobutílico e álcoois isoamílicos) e álcool metílico, segundo Boza 
(1996). Essas análises foram efetuadas utilizando um cromatógrafo CG-037, com detector de ionização de chama e coluna empacotada PAAC 3334-CG.

\subsubsection{Análise estatística}

Nas análises físico-químicas e cromatográficas, o delineamento estatístico foi inteiramente casualisado, com duas repetições.

Os valores médios encontrados em cada análise de cada uma das amostras foram comparados com os valores estabelecidos pela legislação vigente. Para cada um dos componentes foi calculada a média geral de todos os valores obtidos, assim como o desvio padrão da média. Esses valores foram comparados com os padrões de qualidade estabelecidos pela legislação. As análises foram realizadas pelo programa estatístico SAS (Statistical Analysis System, 1996).

\subsection{Envelhecimento de cachaça pela radiação gama e pela madeira carvalho}

Amostras de cachaça com aproximadamente $43^{\circ} \mathrm{GL}$, foram submetidas a dois tratamentos: com e sem irradiação. Esses tratamentos foram divididos em dois subtratamentos: com e sem contato com a madeira. O tratamento com irradiação foi ainda subdividido em: irradiação da cachaça e posterior introdução no tonel; e irradiação do tonel e posterior introdução da cachaça e introdução da cachaça no tonel e irradiação do conjunto (tonel e cachaça). Assim, tivemos os seguintes tratamentos:

1) sem irradiação e sem contato com a madeira

2) sem irradiação e com contato com a madeira

3) sem irradiação e com contato com a madeira anteriormente irradiada

4) com irradiação e sem contato com a madeira

5) com irradiação e com posterior contato com a madeira

6) com irradiação e com contato com a madeira (irradiação do tonel com a cachaça)

As amostras de cachaça do tratamento 1 foram mantidas em bombonas de vidro. As amostras do tratamento 2 foram introduzidas diretamente no tonel de carvalho. 
As amostras de cachaça do tratamento 3 foram colocadas no tonel previamente irradiado onde permaneceu durante todo o período de envelhecimento. As amostras de cachaça a serem irradiadas foram previamente acondicionadas em bombonas de vidro. Após a irradiação, as amostras do tratamento 4 foram mantidas nas bombonas de vidro. As amostras do tratamento 5 foram colocadas no tonel somente após a irradiação. As amostras do tratamento 6 foram colocadas no tonel e o conjunto foi submetido à irradiação.

Os tonéis utilizados neste experimento foram adquiridos no comércio local, confeccionados a partir de tonéis reaproveitados. O volume de cada tonel era de 20 litros. Os tonéis permaneceram sob uma bancada e na posição horizontal durante todo o período do estudo. Para a execução das análises físico-químicas e cromatográficas, as amostras foram retiradas dos tonéis com o auxílio de uma pipeta, através do batoque, localizado na parte superior.

\subsubsection{Irradiação}

A irradiação das amostras e do tonel foi realizada no Laboratório de Irradiação de Alimentos e Radioentomologia, do CENA/USP, em Piracicaba-SP. As cachaças foram irradiadas com doses de 150 Gy, em irradiador panorâmico Gammabeam 650 (MDS Nordion, Ottawa, Canada), emissor de raios gama provenientes do Cobalto-60, com atividade atual de $7,410^{13} \mathrm{~Bq}$.

\subsubsection{Análises físico-químicas}

Foram realizadas análises físico-químicas aos 0, 76, 147, 228, 314, 390 dias de armazenamento.As análises de grau alcoólico, acidez volátil, extrato seco e furfural seguiram as metodologias oficiais descritas em Brasil (1986). A acidez fixa foi obtida pela diferença entre a acidez total e a volátil. A determinação de cobre seguiu a metodologia do Instituto Adolfo Lutz (Pregnolato \& Pregnolato, 1985). A análise de 
tanino seguiu o método da AOAC (1995), e a cor foi analisada através de espectrofotômetro modelo Coleman Jr. III (Silva Júnior, 1999).

\subsubsection{Análises cromatográficas}

Foram realizadas análises cromatográficas aos 0, 76, 147, 228, 314, 390 dias de armazenamento. As análises cromatográficas foram: aldeídos, ésteres, álcoois superiores (n-propílico, álcool isobutílico e álcoois isoamílicos) e álcool metílico, segundo Boza (1996). Essas análises foram efetuadas utilizando um cromatógrafo CG-037, com detector de ionização de chama e coluna empacotada PAAC 3334-CG.

\subsubsection{Análise sensorial}

Ao final do período de envelhecimento as amostras de cachaça foram analisadas sensorialmente, sendo submetidas à análise de aceitação, em relação ao aroma, sabor e aparência.

A equipe composta de 30 provadores voluntários não treinados ${ }^{2}$ e utilizou escala hedônica verbal de 9 pontos. A ficha utilizada seguiu o modelo da figura 2. Os testes foram realizados em cabines individuais do Laboratório de Análise Sensorial do Departamento de Agroindústria, Alimentos e Nutrição da ESALQ/USP.

As amostras foram apresentadas em temperatura ambiente, de forma monádica e seqüencial em cálices transparentes, codificados com algarismos de três dígitos e cobertos com vidro de relógio, que eram retirados no momento do teste. Nos testes de aceitação em relação ao aroma e sabor foi utilizada luz vermelha nas cabines para evitar a influência da cor das amostras no julgamento desses atributos. Já no teste em relação à aceitação foi utilizada luz branca.

\footnotetext{
${ }^{2}$ A pesquisa foi aprovada pelo Comitê de Ética em Pesquisa (CEP) da Faculdade de Odontologia de Piracicaba - FOP, vinculada à UNICAMP (protocolo 105/2004).
} 
NOME: DATA:

Avalie cada uma das amostras codificadas e use a escala abaixo para indicar o quanto você gostou ou desgostou de cada amostra de cachaça.

9. Gostei muitíssimo

8. Gostei muito

7. Gostei moderadamente

6. Gostei ligeiramente

5. Nem gostei nem desgostei

4. Desgostei ligeiramente

3. Desgostei moderadamente

2. Desgostei muito

1. Desgostei muitíssimo

A) Aspire às amostras, uma a uma, e avalie em relação ao AROMA. Descreva o que você mais gostou e menos gostou no AROMA.
AMOSTRA
NOTA
MAIS GOSTOU
MENOS GOSTOU
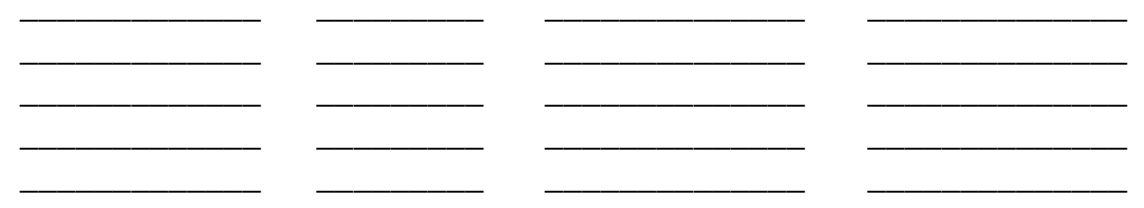

B) Prove as amostras, uma a uma, e avalie em relação ao SABOR. Descreva o que você mais gostou e menos gostou no SABOR.

$$
\text { AMOSTRA }
$$

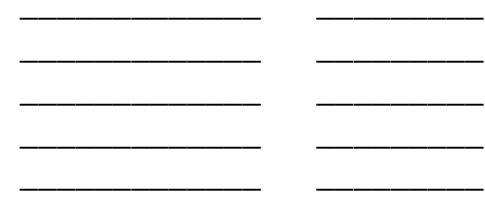

MAIS GOSTOU

MENOS GOSTOU
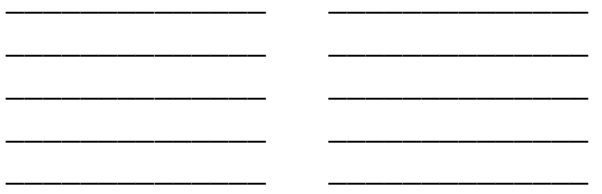

C) Avalie a APARÊNCIA de cada uma das amostras.

Descreva o que você mais gostou e menos gostou na APARÊNCIA.

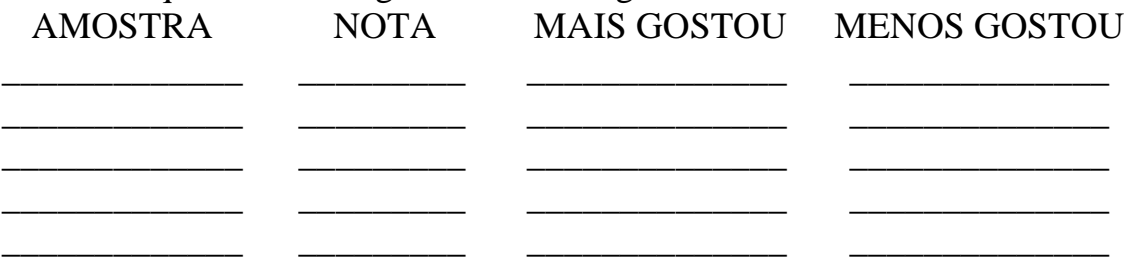

Figura 2 - Modelo de ficha utilizada na avaliação no Teste de Aceitação 


\subsubsection{Análise estatística}

Nas análises físico-químicas e cromatográficas, o delineamento estatístico utilizado foi em blocos casualisados. Foram calculadas as médias do período total de envelhecimento de cada um dos tratamentos. Os resultados destas análises foram avaliados por análise de variância (ANOVA) e Testes de médias de Tukey (5\% de significância).

Os resultados obtidos na análise sensorial através dos testes de aceitação também foram submetidos à análise de variância (ANOVA), com teste F. O teste de Tukey foi realizado para as amostras que obtiveram significância no teste $\mathrm{F}$ ao nível 5\% (Meilgaard et al., 1999).

Todas as análises foram realizadas pelo programa estatístico SAS (Statistical Analysis System, 1996). 


\section{RESULTADOS E DISCUSSÃO}

\subsection{Levantamento da qualidade das cachaças}

Foram analisadas 94 amostras de cachaças, cujos resultados se encontram na tabela 3. Os resultados das análises físico-químicas destas cachaças foram comparados com os padrões de identidade e qualidade estabelecidos pela legislação brasileira vigente. 
Tabela 3. Composição físico-química de cachaças comerciais

\begin{tabular}{|c|c|c|c|c|c|c|c|c|c|}
\hline Componentes & Unidades & AM. 01 & AM. 02 & AM. 03 & AM. 04 & AM. 05 & AM. 06 & AM. 07 & AM. 08 \\
\hline Grau alcoólico & $\% \mathrm{v} / \mathrm{v} 20^{\circ} \mathrm{C}$ & 40,47 & 44,08 & 38,25 & 40,16 & 39,34 & 41,77 & 38,83 & 38,12 \\
\hline \multirow{3}{*}{$\begin{array}{l}\text { Acidez volátil } \\
\text { Ésteres }\end{array}$} & mg ác. acético/100mL etanol 100\% & 38,07 & 41,93 & 13,29 & 23,24 & 16,69 & 10,82 & 6,06 & 12,34 \\
\hline & mg acetato de etila/100mL etanol & & & & & & & & \\
\hline & $100 \%$ & 11,13 & 12,15 & 13,59 & 11,94 & 11,10 & 10,34 & 16,55 & 25,19 \\
\hline \multirow[t]{2}{*}{ Aldeídos } & mg aldeído acético/100mL etanol & & & & & & & & \\
\hline & $100 \%$ & 5,03 & 3,41 & 16,42 & 13,70 & 15,05 & 13,03 & 19,68 & $33,47^{*}$ \\
\hline Furfural & mg/100mL etanol 100\% & 0,09 & 0,08 & 0,01 & 0,00 & 0,00 & 0,02 & 0,00 & 0,00 \\
\hline Isobutílico & mg/100mL etanol 100\% & 74,44 & 82,57 & 65,97 & 69,14 & 54,80 & 60,59 & 80,35 & 95,05 \\
\hline Isoamílico & $\mathrm{mg} / 100 \mathrm{~mL}$ etanol $100 \%$ & 180,40 & 150,11 & 178,59 & 168,53 & 157,21 & 175,18 & 172,57 & 200,48 \\
\hline n-propílico & mg/100mL etanol 100\% & 20,63 & 39,00 & 63,70 & 48,99 & 57,08 & 61,57 & 38,66 & 67,52 \\
\hline Álcoois superiores & $\mathrm{mg} / 100 \mathrm{~mL}$ etanol 100\% & 275,47 & 271,68 & 308,26 & 286,66 & 269,09 & 297,34 & 291,58 & $363,05^{*}$ \\
\hline Congêneres & mg/100mL etanol 100\% & 329,79 & 329,25 & 352,64 & 335,54 & 311,93 & 331,55 & 333,87 & 434,05 \\
\hline Álcool metílico & mg/100mL etanol 100\% & 5,51 & 1,13 & 10,65 & 11,99 & 17,54 & 10,08 & 8,01 & 7,58 \\
\hline Cobre & $\mathrm{mg} / \mathrm{L}$ & 0,46 & 0,35 & 4,67 & 2,18 & 1,26 & 0,64 & 0,74 & 1,86 \\
\hline Extrato seco & $g / L$ & 0,03 & 0,01 & 12,03 & 10,73 & 13,16 & 0,16 & 0,02 & 10,56 \\
\hline Açúcares redutores & $\mathrm{g} / \mathrm{L}$ & - & - & 11,81 & 8,65 & 12,80 & - & - & 8,50 \\
\hline
\end{tabular}

* valores que não atendem aos padrões estabelecidos pela legislação vigente (Brasil, 2005) 
Tabela 3.1 Composição físico-química de cachaças comerciais

\begin{tabular}{|c|c|c|c|c|c|c|c|c|c|}
\hline Componentes & Unidades & AM. 09 & AM. 10 & AM. 11 & AM. 12 & AM. 13 & AM. 14 & AM. 15 & AM. 16 \\
\hline Grau alcoólico & $\% \mathrm{v} / \mathrm{v} 20^{\circ} \mathrm{C}$ & $37,73^{*}$ & 38,25 & 39,59 & 39,02 & 39,34 & 40,16 & $37,80^{*}$ & 44,02 \\
\hline \multirow{3}{*}{$\begin{array}{l}\text { Acidez volátil } \\
\text { Ésteres }\end{array}$} & mg ác. acético/100mL etanol 100\% & 19,32 & 40,89 & 18,12 & 27,72 & 14,95 & 30,45 & 32,04 & 49,69 \\
\hline & mg acetato de etila/100mL etanol & & & & & & & & \\
\hline & $100 \%$ & 27,43 & 0,97 & 8,32 & 14,54 & 13,40 & 4,52 & 2,68 & 6,71 \\
\hline \multirow[t]{2}{*}{ Aldeídos } & mg aldeído acético/100mL etanol & & & & & & & & \\
\hline & $100 \%$ & 14,81 & 4,75 & 19,89 & 17,98 & 21,29 & 6,77 & 5,07 & 10,19 \\
\hline Furfural & mg/100mL etanol 100\% & 0,00 & 0,01 & 0,00 & 0,00 & 0,00 & 0,00 & 0,02 & 0,11 \\
\hline Isobutílico & $\mathrm{mg} / 100 \mathrm{~mL}$ etanol $100 \%$ & 49,89 & 49,93 & 55,33 & 48,77 & 55,77 & 49,77 & 58,28 & 39,20 \\
\hline Isoamílico & $\mathrm{mg} / 100 \mathrm{~mL}$ etanol $100 \%$ & 160,31 & 180,84 & 163,86 & 148,45 & 165,30 & 175,48 & 187,13 & 166,87 \\
\hline n-propílico & mg/100mL etanol 100\% & 55,29 & 52,48 & 53,75 & 82,20 & 51,84 & 22,99 & 27,35 & 25,99 \\
\hline Álcoois superiores & mg/100mL etanol 100\% & 265,49 & 283,25 & 272,94 & 279,42 & 272,91 & 248,24 & 272,76 & 232,06 \\
\hline Congêneres & $\mathrm{mg} / 100 \mathrm{~mL}$ etanol $100 \%$ & 327,05 & 330,75 & 319,27 & 339,66 & 322,55 & 290,72 & 313,39 & 299,90 \\
\hline Álcool metílico & $\mathrm{mg} / 100 \mathrm{~mL}$ etanol $100 \%$ & 6,64 & 5,46 & 6,11 & 5,71 & 9,57 & 7,81 & 7,40 & 11,72 \\
\hline Cobre & $\mathrm{mg} / \mathrm{L}$ & 1,58 & $6,69^{*}$ & 0,74 & 1,58 & 0,75 & 3,47 & 4,57 & 4,47 \\
\hline Extrato seco & $g / L$ & 10,92 & 11,73 & 17,38 & 21,95 & 19,93 & 22,34 & 10,78 & 5,16 \\
\hline Açúcares redutores & $\mathrm{g} / \mathrm{L}$ & 9,01 & 10,52 & 16,35 & 19,61 & 17,00 & 20,23 & 8,45 & 4,89 \\
\hline
\end{tabular}

* valores que não atendem aos padrões estabelecidos pela legislação vigente (Brasil, 2005) 
Tabela 3.2 Composição físico-química de cachaças comerciais

\begin{tabular}{|c|c|c|c|c|c|c|c|c|c|}
\hline Componentes & Unidades & AM. 17 & AM. 18 & AM. 19 & AM. 20 & AM. 21 & AM. 22 & AM. 23 & AM. 24 \\
\hline Grau alcoólico & $\% \mathrm{v} / \mathrm{v} 20^{\circ} \mathrm{C}$ & 50,29 & 41,27 & 39,53 & 38,83 & 39,91 & 38,71 & 40,53 & 42,28 \\
\hline \multirow{3}{*}{$\begin{array}{l}\text { Acidez volátil } \\
\text { Ésteres }\end{array}$} & mg ác. acético/100mL etanol 100\% & 57,06 & 59,27 & 92,22 & $211,69^{*}$ & 41,25 & 100,25 & 139,27 & 41,72 \\
\hline & mg acetato de etila/100mL etanol & & & & & & & & \\
\hline & $100 \%$ & 5,20 & 20,89 & 27,35 & 54,97 & 31,28 & 40,88 & 80,24 & 23,82 \\
\hline \multirow[t]{2}{*}{ Aldeídos } & mg aldeído acético/100mL etanol & & & & & & & & \\
\hline & $100 \%$ & 5,26 & 14,63 & 12,38 & 11,70 & 16,11 & 15,83 & 6,49 & $35,63^{*}$ \\
\hline Furfural & $\mathrm{mg} / 100 \mathrm{~mL}$ etanol $100 \%$ & 0,22 & 0,22 & 0,00 & 0,02 & 0,26 & 0,17 & 0,35 & 0,07 \\
\hline Isobutílico & $\mathrm{mg} / 100 \mathrm{~mL}$ etanol 100\% & 35,73 & 63,31 & 61,45 & 44,07 & 86,34 & 51,46 & 47,61 & 64,34 \\
\hline Isoamílico & $\mathrm{mg} / 100 \mathrm{~mL}$ etanol $100 \%$ & 187,59 & 218,97 & 130,41 & 125,85 & 310,96 & 269,89 & 155,29 & 199,50 \\
\hline n-propílico & $\mathrm{mg} / 100 \mathrm{~mL}$ etanol $100 \%$ & 29,92 & 44,44 & 74,52 & 133,90 & 22,21 & 19,85 & 19,75 & 63,00 \\
\hline Álcoois superiores & mg/100mL etanol 100\% & 253,24 & 326,72 & 266,38 & 303,82 & $419,51^{*}$ & 341,20 & 222,65 & 326,84 \\
\hline Congêneres & $\mathrm{mg} / 100 \mathrm{~mL}$ etanol 100\% & 321,95 & 422,64 & 398,33 & 582,20 & 508,41 & 498,33 & 449,00 & 428,08 \\
\hline Álcool metílico & $\mathrm{mg} / 100 \mathrm{~mL}$ etanol $100 \%$ & 5,42 & 13,09 & 6,89 & 17,26 & 8,35 & 6,74 & 6,40 & 19,34 \\
\hline Cobre & $\mathrm{mg} / \mathrm{L}$ & $6,92^{*}$ & 2,60 & 3,95 & $10,21^{*}$ & 1,86 & $5,22^{*}$ & $12,25^{*}$ & 1,86 \\
\hline Extrato seco & $\mathrm{g} / \mathrm{L}$ & 0,08 & 6,00 & 21,14 & 6,10 & 13,38 & 1,32 & 1,56 & 0,20 \\
\hline Açúcares redutores & $\mathrm{g} / \mathrm{L}$ & - & 5,76 & 18,81 & 5,94 & 13,22 & 1,26 & 1,25 & - \\
\hline
\end{tabular}

* valores que não atendem aos padrões estabelecidos pela legislação vigente (Brasil, 2005) 
Tabela 3.3 Composição físico-química de cachaças comerciais

\begin{tabular}{|c|c|c|c|c|c|c|c|c|c|}
\hline Componentes & Unidades & AM. 25 & AM. 26 & AM. 27 & AM. 28 & AM. 29 & AM. 30 & AM. 31 & AM. 32 \\
\hline Grau alcoólico & $\% \mathrm{v} / \mathrm{v} 20^{\circ} \mathrm{C}$ & 39,40 & $37,60^{*}$ & 41,33 & 40,84 & 41,27 & 38,39 & 39,09 & 39,09 \\
\hline \multirow{3}{*}{$\begin{array}{l}\text { Acidez v } \\
\text { Ésteres }\end{array}$} & mg ác. acético/100mL etanol 100\% & 26,86 & 15,64 & 31,30 & 64,79 & 54,14 & 33,71 & 13,54 & 18,05 \\
\hline & mg acetato de etila/100mL etanol & & & & & & & & \\
\hline & $100 \%$ & 16,38 & 4,49 & 19,93 & 43,17 & 41,52 & 10,51 & 14,04 & 11,96 \\
\hline \multirow[t]{2}{*}{ Aldeídos } & mg aldeído acético/100mL etanol & & & & & & & & \\
\hline & $100 \%$ & 15,67 & 12,42 & 20,17 & 23,27 & 28,27 & $30,15^{*}$ & $62,20^{*}$ & $47,49^{*}$ \\
\hline Furfural & $\mathrm{mg} / 100 \mathrm{~mL}$ etanol $100 \%$ & 0,00 & 0,00 & 0,26 & 0,34 & 0,35 & 0,05 & 0,00 & 0,05 \\
\hline Isobutílico & $\mathrm{mg} / 100 \mathrm{~mL}$ etanol 100\% & 45,70 & 40,75 & 50,20 & 50,61 & 52,39 & 41,42 & 68,50 & 63,50 \\
\hline Isoamílico & $\mathrm{mg} / 100 \mathrm{~mL}$ etanol $100 \%$ & 151,18 & 221,98 & 144,11 & 179,13 & 178,14 & 109,05 & 175,52 & 176,86 \\
\hline n-propílico & $\mathrm{mg} / 100 \mathrm{~mL}$ etanol $100 \%$ & 83,86 & 31,36 & 36,09 & 52,62 & 42,86 & 48,01 & 39,31 & 36,73 \\
\hline Álcoois superiores & $\mathrm{mg} / 100 \mathrm{~mL}$ etanol $100 \%$ & 280,74 & 294,09 & 230,40 & 282,36 & 273,39 & 198,48 & 283,33 & 277,09 \\
\hline Congêneres & $\mathrm{mg} / 100 \mathrm{~mL}$ etanol 100\% & 339,65 & 326,64 & 302,06 & 415,09 & 398,91 & 272,90 & 373,11 & 354,64 \\
\hline Álcool metílico & $\mathrm{mg} / 100 \mathrm{~mL}$ etanol $100 \%$ & 6,59 & 9,59 & 14,92 & 10,21 & 16,28 & 16,60 & 34,75 & 26,78 \\
\hline Cobre & $\mathrm{mg} / \mathrm{L}$ & 2,15 & 0,74 & 0,46 & 1,29 & 1,01 & 0,46 & 1,01 & 1,01 \\
\hline Extrato seco & $\mathrm{g} / \mathrm{L}$ & 0,06 & 0,11 & 0,10 & 1,26 & 0,48 & 7,69 & 7,52 & 9,60 \\
\hline Açúcares redutores & $\mathrm{g} / \mathrm{L}$ & - & - & - & 1,01 & - & 3,90 & 6,32 & 3,90 \\
\hline
\end{tabular}

* valores que não atendem aos padrões estabelecidos pela legislação vigente (Brasil, 2005) 
Tabela 3.4 Composição físico-química de cachaças comerciais

\begin{tabular}{|c|c|c|c|c|c|c|c|c|c|}
\hline Componentes & Unidades & AM. 33 & AM. 34 & AM. 35 & AM. 36 & AM. 37 & AM. 38 & AM. 39 & AM. 40 \\
\hline Grau alcoólico & $\% \mathrm{v} / \mathrm{v} 20^{\circ} \mathrm{C}$ & 39,28 & 43,45 & $37,54^{*}$ & 40,78 & 41,46 & 39,40 & 40,40 & 39,72 \\
\hline \multirow{3}{*}{$\begin{array}{l}\text { Acidez volátil } \\
\text { Ésteres }\end{array}$} & mg ác. acético/100mL etanol 100\% & 23,95 & 37,89 & 18,80 & $183,12^{*}$ & 51,06 & $247,74^{*}$ & 78,59 & 17,76 \\
\hline & mg acetato de etila/100mL etanol & & & & & & & & \\
\hline & $100 \%$ & 12,20 & 34,59 & 14,32 & 83,66 & 20,96 & 157,63 & 12,52 & 15,81 \\
\hline \multirow[t]{2}{*}{ Aldeídos } & mg aldeído acético/100mL etanol & & & & & & & & \\
\hline & $100 \%$ & 18,09 & 11,93 & 14,33 & 5,46 & 11,30 & 16,05 & 15,48 & 22,81 \\
\hline Furfural & mg/100mL etanol 100\% & 0,00 & 0,06 & 0,21 & 0,03 & 0,34 & 0,20 & 0,00 & 0,00 \\
\hline Isobutílico & $\mathrm{mg} / 100 \mathrm{~mL}$ etanol 100\% & 52,84 & 49,51 & 41,06 & 43,19 & 31,43 & 30,41 & 55,89 & 69,13 \\
\hline Isoamílico & $\mathrm{mg} / 100 \mathrm{~mL}$ etanol 100\% & 154,36 & 152,73 & 193,99 & 110,44 & 136,48 & 94,33 & 134,77 & 157,35 \\
\hline n-propílico & $\mathrm{mg} / 100 \mathrm{~mL}$ etanol 100\% & 34,26 & 68,11 & 46,94 & 118,49 & 33,12 & 290,31 & 75,18 & 69,99 \\
\hline Álcoois superiores & $\mathrm{mg} / 100 \mathrm{~mL}$ etanol 100\% & 241,46 & 270,35 & 281,99 & 272,12 & 201,03 & $415,05^{*}$ & 265,84 & 296,47 \\
\hline Congêneres & $\mathrm{mg} / 100 \mathrm{~mL}$ etanol 100\% & 295,70 & 355,99 & 329,65 & 544,39 & 284,69 & $836,67^{*}$ & 372,43 & 352,85 \\
\hline Álcool metílico & $\mathrm{mg} / 100 \mathrm{~mL}$ etanol $100 \%$ & 7,73 & 6,35 & 5,61 & 4,86 & 5,99 & 1,35 & 4,35 & 16,69 \\
\hline Cobre & $\mathrm{mg} / \mathrm{L}$ & 1,29 & 0,46 & 2,74 & 0,46 & 1,86 & $9,44^{*}$ & 2,15 & 5,00 \\
\hline Extrato seco & $\mathrm{g} / \mathrm{L}$ & 18,49 & 0,31 & 0,18 & 0,36 & 0,22 & 0,02 & 26,76 & 22,12 \\
\hline Açúcares redutores & $\mathrm{g} / \mathrm{L}$ & 16,68 & - & - & - & - & - & 24,19 & 17,56 \\
\hline
\end{tabular}

* valores que não atendem aos padrões estabelecidos pela legislação vigente (Brasil, 2005) 
Tabela 3.5 Composição físico-química de cachaças comerciais

\begin{tabular}{|c|c|c|c|c|c|c|c|c|c|}
\hline Componentes & Unidades & AM. 41 & AM. 42 & AM. 43 & AM. 44 & AM. 45 & AM. 46 & AM. 47 & AM. 48 \\
\hline Grau alcoólico & $\% \mathrm{v} / \mathrm{v} 20^{\circ} \mathrm{C}$ & 41,33 & 40,65 & 38,19 & 39,02 & 38,39 & 39,15 & 38,71 & 39,66 \\
\hline \multirow{3}{*}{$\begin{array}{l}\text { Acidez volátil } \\
\text { Ésteres }\end{array}$} & mg ác. acético/100mL etanol 100\% & 17,07 & 57,86 & 12,63 & 9,04 & 20,83 & 20,43 & 9,72 & 19,92 \\
\hline & mg acetato de etila/100mL etanol & & & & & & & & \\
\hline & $100 \%$ & 15,24 & 42,53 & 18,02 & 9,01 & 10,11 & 11,13 & 9,58 & 15,01 \\
\hline \multirow[t]{2}{*}{ Aldeídos } & mg aldeído acético/100mL etanol & & & & & & & & \\
\hline & $100 \%$ & 11,54 & 20,47 & 24,43 & 13,77 & $42,40^{*}$ & $49,02^{*}$ & 13,61 & 21,91 \\
\hline Furfural & $\mathrm{mg} / 100 \mathrm{~mL}$ etanol 100\% & 0,00 & 0,13 & 0,00 & 0,00 & 0,00 & 0,02 & 0,00 & 0,00 \\
\hline Isobutílico & $\mathrm{mg} / 100 \mathrm{~mL}$ etanol $100 \%$ & 56,39 & 53,45 & 47,78 & 28,64 & 65,67 & 58,76 & 49,04 & 47,39 \\
\hline Isoamílico & mg/100mL etanol 100\% & 189,30 & 167,61 & 147,50 & 90,14 & 196,81 & 144,13 & 156,83 & 161,50 \\
\hline n-propílico & mg/100mL etanol 100\% & 55,43 & 44,17 & 48,08 & 36,37 & 42,46 & 38,61 & 86,68 & 99,53 \\
\hline Álcoois superiores & mg/100mL etanol 100\% & 301,12 & 265,23 & 243,36 & 155,15 & 304,94 & 241,50 & 292,55 & 308,42 \\
\hline Congêneres & mg/100mL etanol 100\% & 344,97 & 386,22 & 298,44 & $186,97^{*}$ & 378,28 & 322,10 & 325,46 & 365,26 \\
\hline Álcool metílico & mg/100mL etanol 100\% & 5,05 & 6,71 & 9,35 & 5,11 & 19,53 & 22,30 & 4,54 & 9,24 \\
\hline Cobre & $\mathrm{mg} / \mathrm{L}$ & 0,46 & 0,19 & 0,00 & 0,19 & 1,01 & 1,01 & 0,00 & 0,00 \\
\hline Extrato seco & $\mathrm{g} / \mathrm{L}$ & 0,09 & 0,38 & 11,62 & 4,45 & 3,42 & 6,14 & 0,16 & 0,28 \\
\hline Açúcares redutores & $\mathrm{g} / \mathrm{L}$ & - & - & 10,77 & 3,89 & 2,56 & 3,26 & - & - \\
\hline
\end{tabular}

* valores que não atendem aos padrões estabelecidos pela legislação vigente (Brasil, 2005) 
Tabela 3.6 Composição físico-química de cachaças comerciais

\begin{tabular}{|c|c|c|c|c|c|c|c|c|c|}
\hline Componentes & Unidades & AM. 49 & AM. 50 & AM. 51 & AM. 52 & AM. 53 & AM. 54 & AM. 55 & AM. 56 \\
\hline Grau alcoólico & $\% \mathrm{v} / \mathrm{v} 20^{\circ} \mathrm{C}$ & 38,58 & 38,96 & $37,14^{*}$ & 38,77 & 38,71 & 38,83 & 39,21 & $37,47^{*}$ \\
\hline \multirow{3}{*}{$\begin{array}{l}\text { Acidez volátil } \\
\text { Ésteres }\end{array}$} & mg ác. acético/100mL etanol 100\% & 15,24 & 69,43 & 25,33 & 39,43 & 6,38 & 15,14 & 18,00 & 56,49 \\
\hline & mg acetato de etila/100mL etanol & & & & & & & & \\
\hline & $100 \%$ & 18,26 & 42,44 & 23,40 & 22,61 & 18,82 & 22,18 & 11,16 & 13,42 \\
\hline \multirow[t]{2}{*}{ Aldeídos } & mg aldeído acético/100mL etanol & & & & & & & & \\
\hline & $100 \%$ & $82,47^{*}$ & 20,15 & 20,03 & 22,23 & 2,77 & 3,85 & $35,97^{*}$ & 20,86 \\
\hline Furfural & mg/100mL etanol 100\% & 0,00 & 0,05 & 0,00 & 0,00 & 0,05 & 0,00 & 0,00 & 0,00 \\
\hline Isobutílico & $\mathrm{mg} / 100 \mathrm{~mL}$ etanol 100\% & 82,28 & 52,80 & 70,30 & 45,64 & 44,72 & 48,29 & 59,23 & 58,81 \\
\hline Isoamílico & $\mathrm{mg} / 100 \mathrm{~mL}$ etanol 100\% & 183,31 & 175,12 & 200,50 & 156,61 & 82,92 & 130,86 & 212,79 & 192,63 \\
\hline n-propílico & $\mathrm{mg} / 100 \mathrm{~mL}$ etanol 100\% & 65,36 & 80,35 & 48,41 & 90,30 & 24,82 & 18,76 & 52,49 & 61,57 \\
\hline Álcoois superiores & mg/100mL etanol 100\% & 330,95 & 308,27 & 319,21 & 292,55 & 152,46 & 197,91 & 324,51 & 313,01 \\
\hline Congêneres & $\mathrm{mg} / 100 \mathrm{~mL}$ etanol 100\% & 446,92 & 440,34 & 387,97 & 376,82 & $180,48^{*}$ & 239,08 & 390,97 & 403,78 \\
\hline Álcool metílico & $\mathrm{mg} / 100 \mathrm{~mL}$ etanol $100 \%$ & 37,75 & 6,95 & 8,52 & 8,28 & 4,35 & 0,78 & 19,86 & 8,23 \\
\hline Cobre & $\mathrm{mg} / \mathrm{L}$ & 2,44 & 0,46 & 0,46 & 0,74 & 0,00 & 0,00 & 0,00 & 3,34 \\
\hline Extrato seco & $\mathrm{g} / \mathrm{L}$ & 9,89 & 0,20 & 18,66 & 18,16 & 18,02 & 3,02 & 19,04 & 17,59 \\
\hline Açúcares redutores & $\mathrm{g} / \mathrm{L}$ & 8,31 & - & 16,25 & 16,63 & 10,78 & 2,51 & 15,91 & 9,63 \\
\hline
\end{tabular}

* valores que não atendem aos padrões estabelecidos pela legislação vigente (Brasil, 2005) 
Tabela 3.7 Composição físico-química de cachaças comerciais

\begin{tabular}{|c|c|c|c|c|c|c|c|c|c|}
\hline Componentes & Unidades & AM. 57 & AM. 58 & AM. 59 & AM. 60 & AM. 61 & AM. 62 & AM. 63 & AM. 64 \\
\hline Grau alcoólico & $\% \mathrm{v} / \mathrm{v} 20^{\circ} \mathrm{C}$ & 38,71 & 38,96 & 39,59 & 39,40 & 39,53 & 39,15 & 38,83 & 38,32 \\
\hline Acidez volátil & mg ác. acético/100mL etanol 100\% & 12,46 & 12,75 & 50,50 & 23,88 & 52,06 & 57,07 & 49,97 & 58,31 \\
\hline Ésteres & mg acetato de etila/100mL etanol & & & & & & & & \\
\hline \multirow{3}{*}{ Aldeídos } & $100 \%$ & 11,84 & 14,29 & 124,35 & 20,02 & 25,09 & 23,72 & 17,43 & 18,95 \\
\hline & mg aldeído acético/100mL etanol & & & & & & & & \\
\hline & $100 \%$ & $40,09^{*}$ & $33,69^{*}$ & $32,22^{*}$ & 20,23 & 14,55 & 19,15 & 9,50 & 11,18 \\
\hline Furfural & mg/100mL etanol 100\% & 0,00 & 0,00 & 0,21 & 0,00 & 0,00 & 0,01 & 0,01 & 0,01 \\
\hline Isobutílico & $\mathrm{mg} / 100 \mathrm{~mL}$ etanol $100 \%$ & 66,14 & 63,41 & 36,55 & 59,73 & 44,00 & 54,56 & 51,42 & 59,73 \\
\hline Isoamílico & mg/100mL etanol 100\% & 216,34 & 199,59 & 136,86 & 166,42 & 184,58 & 182,50 & 180,75 & 197,49 \\
\hline n-propílico & $\mathrm{mg} / 100 \mathrm{~mL}$ etanol $100 \%$ & 60,93 & 67,45 & 47,63 & 59,69 & 73,89 & 28,08 & 51,79 & 63,56 \\
\hline Álcoois superiores & mg/100mL etanol 100\% & 343,41 & 330,45 & 221,04 & 285,84 & 302,47 & 265,14 & 283,96 & 320,78 \\
\hline Congêneres & $\mathrm{mg} / 100 \mathrm{~mL}$ etanol $100 \%$ & 407,80 & 391,18 & 428,32 & 349,97 & 394,17 & 365,09 & 360,87 & 409,23 \\
\hline Álcool metílico & $\mathrm{mg} / 100 \mathrm{~mL}$ etanol $100 \%$ & 20,77 & 14,87 & 16,01 & 8,16 & 4,24 & 7,23 & 3,51 & 3,62 \\
\hline Cobre & $\mathrm{mg} / \mathrm{L}$ & 0,46 & 2,44 & $9,06^{*}$ & 1,86 & 2,44 & 4,90 & $6,55^{*}$ & 4,26 \\
\hline Extrato seco & $\mathrm{g} / \mathrm{L}$ & 19,32 & 18,40 & 0,78 & 21,03 & 0,36 & 11,06 & 0,18 & 0,31 \\
\hline Açúcares redutores & $\mathrm{g} / \mathrm{L}$ & 18,12 & 17,72 & - & 20,02 & - & 9,96 & - & - \\
\hline
\end{tabular}

* valores que não atendem aos padrões estabelecidos pela legislação vigente (Brasil, 2005) 
Tabela 3.8 Composição físico-química de cachaças comerciais

\begin{tabular}{|c|c|c|c|c|c|c|c|c|c|}
\hline Componentes & Unidades & AM. 65 & AM. 66 & AM. 67 & AM. 68 & AM. 69 & AM. 70 & AM. 71 & AM. 72 \\
\hline Grau alcoólico & $\% \mathrm{v} / \mathrm{v} 20^{\circ} \mathrm{C}$ & 39,40 & 48,28 & 39,78 & 39,66 & 38,58 & 43,79 & 43,62 & 38,71 \\
\hline \multirow{3}{*}{$\begin{array}{l}\text { Acidez volátil } \\
\text { Ésteres }\end{array}$} & mg ác. acético/100mL etanol 100\% & 74,62 & $151,02^{*}$ & 23,65 & $180,88^{*}$ & 106,69 & 147,97 & 70,10 & $154,94^{*}$ \\
\hline & mg acetato de etila/100mL etanol & & & & & & & & \\
\hline & $100 \%$ & 54,71 & $260,08^{*}$ & 32,31 & $251,76^{*}$ & $222,62^{*}$ & $230,13^{*}$ & 92,76 & 50,14 \\
\hline \multirow[t]{2}{*}{ Aldeídos } & mg aldeído acético/100mL etanol & & & & & & & & \\
\hline & $100 \%$ & 14,23 & 10,95 & 27,08 & 22,18 & 24,90 & $35,17^{*}$ & 21,12 & $31,80^{*}$ \\
\hline Furfural & $\mathrm{mg} / 100 \mathrm{~mL}$ etanol $100 \%$ & 0,06 & 0,17 & 0,00 & 0,19 & 0,12 & 0,50 & 0,05 & 0,33 \\
\hline Isoutílico & $\mathrm{mg} / 100 \mathrm{~mL}$ etanol $100 \%$ & 30,67 & 16,40 & 70,51 & 55,90 & 62,05 & 70,59 & 33,33 & 69,09 \\
\hline Isoamílico & $\mathrm{mg} / 100 \mathrm{~mL}$ etanol $100 \%$ & 128,71 & 49,71 & 184,35 & 150,49 & 141,06 & 199,12 & 123,32 & 203,76 \\
\hline n-propílico & $\mathrm{mg} / 100 \mathrm{~mL}$ etanol $100 \%$ & 61,88 & 158,48 & 68,84 & 55,72 & 100,84 & 68,00 & 41,58 & 60,29 \\
\hline Álcoois superiores & $\mathrm{mg} / 100 \mathrm{~mL}$ etanol $100 \%$ & 221,26 & 224,59 & 323,70 & 262,11 & 303,95 & 337,71 & 198,23 & 333,14 \\
\hline Congêneres & $\mathrm{mg} / 100 \mathrm{~mL}$ etanol $100 \%$ & 364,88 & 646,81 & 406,74 & $717,12^{*}$ & $658,28^{*}$ & $751,48^{*}$ & 382,26 & 570,35 \\
\hline Álcool metílico & $\mathrm{mg} / 100 \mathrm{~mL}$ etanol $100 \%$ & 6,25 & 0,00 & 5,71 & 0,50 & 0,40 & 6,63 & 10,11 & 22,41 \\
\hline Cobre & $\mathrm{mg} / \mathrm{L}$ & $5,55^{*}$ & 3,05 & 0,46 & $5,88^{*}$ & $5,22^{*}$ & 1,01 & 1,58 & $8,32^{*}$ \\
\hline Extrato seco & $\mathrm{g} / \mathrm{L}$ & 0,33 & 1,22 & 29,05 & 0,16 & 0,14 & 0,50 & 0,52 & 0,23 \\
\hline Açúcares redutores & $\mathrm{g} / \mathrm{L}$ & - & 0,99 & 27,77 & - & - & - & - & - \\
\hline
\end{tabular}

* valores que não atendem aos padrões estabelecidos pela legislação vigente (Brasil, 2005) 
Tabela 3.9 Composição físico-química de cachaças comerciais

\begin{tabular}{|c|c|c|c|c|c|c|c|c|c|}
\hline Componentes & Unidades & AM. 73 & AM. 74 & AM. 75 & AM. 76 & AM. 77 & AM. 78 & AM. 79 & AM. 80 \\
\hline Grau alcoólico & $\% \mathrm{v} / \mathrm{v} 20^{\circ} \mathrm{C}$ & 42,04 & 43,10 & 40,16 & $34,24^{*}$ & $37,86^{*}$ & 39,28 & 38,12 & 41,98 \\
\hline Acidez volátil & mg ác. acético/100mL etanol 100\% & 137,07 & 68,21 & 41,00 & 113,34 & $208,11^{*}$ & 19,46 & 52,44 & 19,80 \\
\hline Ésteres & mg acetato de etila/100mL etanol & & & & & & & & \\
\hline & $100 \%$ & $418,85^{*}$ & 39,73 & 14,55 & 15,32 & 25,32 & 17,80 & 27,92 & 14,62 \\
\hline \multirow[t]{2}{*}{ Aldeídos } & mg aldeído acético/100mL etanol & & & & & & & & \\
\hline & $100 \%$ & 11,64 & $35,02^{*}$ & 14,10 & 10,30 & 12,67 & 20,23 & 28,39 & 8,46 \\
\hline Furfural & mg/100mL etanol 100\% & 0,21 & 0,11 & 0,13 & 1,28 & 1,21 & 0,00 & 0,25 & 0,03 \\
\hline Isoutílico & $\mathrm{mg} / 100 \mathrm{~mL}$ etanol $100 \%$ & 16,43 & 70,00 & 56,56 & 34,24 & 34,01 & 54,56 & 27,80 & 46,16 \\
\hline Isoamílico & $\mathrm{mg} / 100 \mathrm{~mL}$ etanol $100 \%$ & 68,53 & 217,98 & 151,93 & 124,06 & 126,67 & 164,22 & 143,21 & 154,89 \\
\hline n-propílico & mg/100mL etanol 100\% & 71,08 & 60,49 & 57,99 & 41,18 & 48,12 & 72,14 & 41,07 & 20,88 \\
\hline Álcoois superiores & mg/100mL etanol 100\% & 156,04 & 348,47 & 266,48 & 199,48 & 208,80 & 290,92 & 212,08 & 221,93 \\
\hline Congêneres & $\mathrm{mg} / 100 \mathrm{~mL}$ etanol 100\% & $725,55^{*}$ & 493,56 & 336,26 & 339,72 & 456,11 & 348,41 & 321,08 & 264,84 \\
\hline Álcool metílico & mg/100mL etanol 100\% & 0,95 & 3,90 & 3,99 & 3,33 & 5,28 & 6,35 & 9,08 & 2,71 \\
\hline Cobre & $\mathrm{mg} / \mathrm{L}$ & $7,25^{*}$ & 0,74 & 0,46 & 0,74 & 3,03 & 1,01 & 3,03 & 1,58 \\
\hline Extrato seco & $g / L$ & 0,16 & 0,28 & 0,24 & 0,13 & 2,76 & 18,77 & 0,27 & 0,06 \\
\hline Açúcares redutores & $\mathrm{g} / \mathrm{L}$ & - & - & 0,19 & - & 2,22 & 17,13 & - & - \\
\hline
\end{tabular}

* valores que não atendem aos padrões estabelecidos pela legislação vigente (Brasil, 2005) 
Tabela 3.10 Composição físico-química de cachaças comerciais

\begin{tabular}{|c|c|c|c|c|c|c|c|c|c|}
\hline Componentes & Unidades & AM. 81 & AM. 82 & AM. 83 & AM. 84 & AM. 85 & AM. 86 & AM. 87 & AM. 88 \\
\hline Grau alcoólico & $\% \mathrm{v} / \mathrm{v} 20^{\circ} \mathrm{C}$ & 47,06 & 39,66 & 39,53 & 42,04 & 47,49 & 41,83 & $37,41^{*}$ & 42,10 \\
\hline \multirow{3}{*}{$\begin{array}{l}\text { Acidez volátil } \\
\text { Ésteres }\end{array}$} & mg ác. acético/100mL etanol 100\% & $177,97^{*}$ & 90,16 & 63,11 & 89,02 & 15,26 & 19,88 & 17,47 & 96,23 \\
\hline & mg acetato de etila/100mL etanol & & & & & & & & \\
\hline & $100 \%$ & $224,03^{*}$ & 72,15 & 24,31 & 129,10 & 49,13 & 8,87 & 21,96 & 64,49 \\
\hline \multirow[t]{2}{*}{ Aldeídos } & mg aldeído acético/100mL etanol & & & & & & & & \\
\hline & $100 \%$ & 17,69 & 13,77 & 15,45 & 17,87 & 19,66 & 8,04 & 8,84 & 15,89 \\
\hline Furfural & mg/100mL etanol 100\% & 0,00 & 0,08 & 0,13 & 0,22 & 0,05 & 0,00 & 0,04 & 0,13 \\
\hline Isobutílico & $\mathrm{mg} / 100 \mathrm{~mL}$ etanol 100\% & 57,89 & 55,57 & 38,62 & 54,22 & 38,53 & 48,84 & 35,36 & 57,61 \\
\hline Isoamílico & mg/100mL etanol 100\% & 89,96 & 186,39 & 138,87 & 195,32 & 110,34 & 194,02 & 132,18 & 142,49 \\
\hline n-propílico & $\mathrm{mg} / 100 \mathrm{~mL}$ etanol $100 \%$ & 168,16 & 35,25 & 48,18 & 35,60 & 43,16 & 69,70 & 42,13 & 127,91 \\
\hline Álcoois superiores & $\mathrm{mg} / 100 \mathrm{~mL}$ etanol 100\% & 316,01 & 277,21 & 225,67 & 285,14 & 192,03 & 312,56 & 209,67 & 328,01 \\
\hline Congêneres & $\mathrm{mg} / 100 \mathrm{~mL}$ etanol 100\% & $735,70^{*}$ & 453,37 & 328,67 & 521,35 & 276,13 & 349,35 & 257,98 & 504,75 \\
\hline Álcool metílico & mg/100mL etanol 100\% & 1,12 & 2,67 & 6,51 & 0,59 & 4,69 & 5,84 & 3,91 & 6,52 \\
\hline Cobre & $\mathrm{mg} / \mathrm{L}$ & 2,15 & 4,26 & 3,34 & 4,90 & 0,00 & 2,74 & 0,46 & 1,29 \\
\hline Extrato seco & $\mathrm{g} / \mathrm{L}$ & 0,04 & 0,16 & 0,01 & 0,98 & 0,13 & 0,05 & 0,14 & 0,20 \\
\hline Açúcares redutores & $\mathrm{g} / \mathrm{L}$ & - & - & - & - & - & - & - & - \\
\hline
\end{tabular}


Tabela 3.11 Composição físico-química de cachaças

\begin{tabular}{|c|c|c|c|c|c|c|c|}
\hline Componentes & Unidades & AM. 89 & AM. 90 & AM. 91 & AM. 92 & AM. 93 & AM. 94 \\
\hline Grau alcoólico & $\% \mathrm{v} / \mathrm{v} 20^{\circ} \mathrm{C}$ & 42,28 & 47,33 & 40,47 & 40,34 & 40,47 & 42,51 \\
\hline \multirow{3}{*}{$\begin{array}{l}\text { Acidez volátil } \\
\text { Ésteres }\end{array}$} & mg ác. acético/100mL etanol 100\% & 115,20 & 71,43 & 36,69 & 38,28 & 17,44 & 44,26 \\
\hline & mg acetato de etila/100mL etanol & & & & & & \\
\hline & $100 \%$ & 95,92 & 111,95 & 60,92 & 79,18 & 31,40 & 59,46 \\
\hline \multirow[t]{2}{*}{ Aldeídos } & mg aldeído acético/100mL etanol & & & & & & \\
\hline & $100 \%$ & 23,25 & 19,21 & 30,00 & $30,34^{*}$ & 15,77 & 15,35 \\
\hline Furfural & mg/100mL etanol 100\% & 0,16 & 0,12 & 0,04 & 0,06 & 0,04 & 0,17 \\
\hline Isobutílico & mg/100mL etanol 100\% & 60,77 & 35,27 & 54,26 & 94,77 & 52,04 & 43,59 \\
\hline Isoamílico & mg/100mL etanol 100\% & 148,75 & 145,65 & 204,11 & 323,39 & 201,29 & 181,07 \\
\hline n-propílico & $\mathrm{mg} / 100 \mathrm{~mL}$ etanol 100\% & 120,10 & 66,37 & 31,66 & 25,19 & 62,18 & 38,62 \\
\hline Álcoois superiores & mg/100mL etanol 100\% & 329,62 & 247,29 & 290,03 & $443,35^{*}$ & 315,51 & 263,28 \\
\hline Congêneres & $\mathrm{mg} / 100 \mathrm{~mL}$ etanol 100\% & 564,15 & 450,00 & 417,68 & 591,21 & 380,16 & 382,52 \\
\hline Álcool metílico & mg/100mL etanol 100\% & 6,68 & 1,92 & 4,28 & 5,66 & 3,06 & 0,56 \\
\hline Cobre & $\mathrm{mg} / \mathrm{L}$ & 1,58 & $6,21^{*}$ & 3,34 & 3,95 & 2,44 & 1,58 \\
\hline Extrato seco & $\mathrm{g} / \mathrm{L}$ & 0,28 & 0,12 & 0,14 & 0,15 & 0,08 & 0,31 \\
\hline Açúcares redutores & $\mathrm{g} / \mathrm{L}$ & - & - & - & - & - & - \\
\hline
\end{tabular}


As características gerais e sensoriais de cachaça envelhecida são dadas pela somatória dos congêneres e dos extrativos da madeira ao longo do tempo de envelhecimento. Portanto, análises como extrato seco não são de muita importância na avaliação do tempo de envelhecimento, mas podem ser úteis para avaliar teores de sólidos solúveis e como indicativo de eventual necessidade de determinação de açúcares redutores totais.

Assim, no presente trabalho as cachaças foram avaliadas quanto à concentração de extrato seco como indicativo de necessidade de análises mais específicas como açúcares redutores, e eventualmente para a confirmação da presença de sais utilizados como corretivos.

As análises de açúcares redutores totais mostraram em alguns casos que os rótulos utilizados foram inadvertidamente trocados por conterem açúcares acima dos $6 \mathrm{~g} \mathrm{~L}^{-1} \mathrm{e}$ não ser caracterizada de “adoçada” ou o inverso, quando o limite de açúcares está muito aquém da legislação e no rótulo consta a especificação “adoçada”.

Quanto aos padrões de identidade e qualidade para a aguardente de cana e para cachaça estabelecidos em Brasil (1974), 56 amostras (60\% do total) encontraram-se não conformes em pelo menos um dos componentes analisados, sendo álcoois superiores o menos respeitado (Tabela 4). Algumas delas estão às margens dos padrões, o que pode ser interpretado como erro de metodologia.

Para o componente grau alcoólico, essas pequenas variações em relação à concentração estabelecida pela legislação podem indicar também imprecisão dos equipamentos utilizados na sua determinação, além de possíveis erros no ponto de corte da destilação ou da diluição da cachaça e condições de acondicionamento dos tonéis.

As mesmas amostras avaliadas em relação à Instrução Normativa $n^{\circ} 13$ de 29 de junho de 2005 foram reduzidas para 45 (48\% do total). As 11 marcas que foram verificadas como conformes possuíam fora das especificações apenas concentração de álcoois superiores, que passou de componente com mais notificações de cachaças irregulares (31 amostras) para o menos apontado em desacordo com os padrões legais (4 amostras), como mostrado na tabela 4. 
Tabela 4. Número de amostras de cachaça que não atenderam ao respectivo padrão de identidade e qualidade estabelecido pela legislação brasileira

\begin{tabular}{lcc}
\hline \multicolumn{1}{c}{ Componentes } & $\begin{array}{r}\text { Número de amostras } \\
\text { Irregulares (Brasil, 1974) }\end{array}$ & $\begin{array}{c}\text { Número de amostras } \\
\text { Irregulares (Brasil, 2005) }\end{array}$ \\
\hline Grau alcoólico & 9 & 9 \\
Acidez volátil & 8 & 8 \\
Ésteres & 6 & 6 \\
Aldeídos & 16 & 16 \\
Álcoois superiores & 31 & 8 \\
Congêneres & 8 & 14 \\
Cobre & 14 & 4 \\
\hline
\end{tabular}

De qualquer forma, a presente discussão tem o caráter de levantar alguns problemas de produção, estandardização e envase principalmente por pequenas indústrias ainda pouco preparadas para controle e garantia da qualidade e ao consumidor como uma contribuição ao conhecimento desses processos e a exigência legal, pois quem aprecia e consome é o mais exigente fiscal do produto, cuja qualidade deverá ser melhorada com a emissão de certificação.

A tabela 5 mostra os valores mínimo e máximo, a média geral e o desvio-padrão dos resultados das análises físico-químicas das cachaças. Nesta tabela foram excluídos os componentes extrato seco e açúcares redutores porque estas determinações apresentam muita variação entre as cachaças adoçadas e as não adoçadas, o que originaria uma média que não condiria com a realidade do conjunto das cachaças analisadas. 
Tabela 5. Composição físico-química média das cachaças analisadas, incluindo o desvio padrão dos componentes das amostras de cachaça

\begin{tabular}{|c|c|c|c|c|}
\hline Componentes & Unidades & $\begin{array}{c}\text { Valor } \\
\text { Máximo }\end{array}$ & $\begin{array}{c}\text { Valor } \\
\text { Mínimo }\end{array}$ & $\begin{array}{c}\text { Média } \pm \\
\text { Desvio Padrão }\end{array}$ \\
\hline Grau alcoólico & $\% \mathrm{v} / \mathrm{v} 20^{\circ} \mathrm{C}$ & 50,29 & 34,24 & $40,23 \pm 2,54$ \\
\hline \multirow{2}{*}{ Acidez volátil } & mg ác. acético/100mL & & & \\
\hline & etanol $100 \%$ & 247,74 & 6,06 & $55,82 \pm 52,37$ \\
\hline \multirow[t]{2}{*}{ Ésteres } & mg acetato de etila/100mL & & & \\
\hline & etanol $100 \%$ & 418,85 & 0,97 & $46,27 \pm 67,54$ \\
\hline \multirow[t]{2}{*}{ Aldeídos } & mg aldeído acético/100mL & & & \\
\hline & etanol $100 \%$ & 82,47 & 2,77 & $19,78 \pm 12,56$ \\
\hline Furfural & mg/100mL etanol $100 \%$ & 1,28 & 0,00 & $0,11 \pm 0,20$ \\
\hline Isobutílico & $\mathrm{mg} / 100 \mathrm{~mL}$ etanol $100 \%$ & 95,05 & 16,40 & $53,31 \pm 14,97$ \\
\hline Isoamílico & $\mathrm{mg} / 100 \mathrm{~mL}$ etanol $100 \%$ & 323,39 & 49,71 & $165,74 \pm 42,37$ \\
\hline n-propílico & $\mathrm{mg} / 100 \mathrm{~mL}$ etanol $100 \%$ & 290,31 & 18,76 & $59,29 \pm 37,27$ \\
\hline \multicolumn{5}{|l|}{ Álcoois } \\
\hline superiores & mg/100mL etanol 100\% & 443,35 & 152,46 & $278,49 \pm 52,73$ \\
\hline Congêneres & $\mathrm{mg} / 100 \mathrm{~mL}$ etanol $100 \%$ & 836,37 & 180,48 & $400,46 \pm 121,88$ \\
\hline Álcool metílico & mg/100mL etanol 100\% & 37,75 & 0,00 & $8,53 \pm 6,95$ \\
\hline Cobre & $\mathrm{mg} / \mathrm{L}$ & 12,25 & 0,00 & $2,57 \pm 2,57$ \\
\hline
\end{tabular}

Observando a tabela 5, pode-se notar que, excluindo o grau alcoólico houve uma grande variação na concentração dos demais componentes, indicando que a bebida cachaça de cana apresenta uma grande variabilidade de composição química entre as marcas produzidas no Brasil.

Os resultados estão alinhados com os de Vargas \& Glória (1995), os quais determinaram que 65\% de 511 amostras de cachaças do estado de Minas Gerais, que foram analisadas no período de 1989 a 1992, não atenderam aos padrões estabelecidos na legislação nacional. Esse percentual manteve-se praticamente constante durante esses anos. Os parâmetros associados ao não atendimento aos padrões oficiais de identidade e qualidade da bebida foram cobre, acidez volátil, ésteres e álcoois superiores. 
Stupiello (1992), também constatou que as cachaças produzidas no Brasil continuam apresentando considerável variação nas suas composições químicas analisando 185 marcas de diversas origens e individualmente os componentes que mais apresentaram variação foram álcoois superiores, acidez e ésteres.

No presente estudo os parâmetros que mais oscilaram foram os mesmos encontrados por Stupiello (1992). A faixa de maior freqüência das amostras estavam de acordo com os padrões atuais para esses três componentes.

Álcoois superiores foi o parâmetro com o maior número de amostras irregulares, de acordo com Brasil (1974), porém atualizando a verificação pelos padrões vigentes de 2005 sua quantidade permanece acima do permitido em uma pequena porcentagem das marcas analisadas (4\%), concordando com os resultados obtidos por Vargas \& Glória (1995) com média de 4,2\% para o período do estudo.

Do total de amostras analisadas, 15\% apresentaram teor de cobre além do limite estabelecido (valor máximo verificado de $12 \mathrm{mg} \mathrm{mL}^{-1}$ ), quantidade bem inferior aos 32\% encontrados por Vargas \& Glória (1995), indicando que atualmente existe uma maior preocupação por parte da maioria dos produtores em reduzir a contaminação por cobre de suas cachaças buscando atender as exigências legais e garantir a saúde do consumidor.

Essa é a primeira providência a ser tomada por produtores que almejam exportar a cachaça, substituindo alambique/condensador por outros materiais, por exemplo. Uma alternativa ainda pouco conhecida e estudada é a utilização de carvão ativado. Segundo estudo realizado por Lima (2005) em cachaças com cobre em excesso (teores entre 8 e 10 mg L ${ }^{-1}$ ), o carvão ativado em concentrações de $2 \mathrm{~g} \mathrm{~L}^{-1}$ e $4 \mathrm{~g} \mathrm{~L}^{-1}$ promoveu remoção do cobre da cachaça, porém a quantidade extraída não atingiu o limite máximo aceitável.

O álcool metílico é um álcool indesejável na cachaça. Os teores encontrados neste trabalho estão de acordo com a lei, assim como resultados obtidos por Stupiello (1992). Já Vargas \& Glória (1995), não detectaram sequer traços deste contaminante nas amostras comerciais analisadas possivelmente pela metodologia oficial utilizada para análise deste componente.

O controle de qualidade de todas as etapas de produção da cachaça é fundamental ferramenta para que a legislação seja cumprida através dos parâmetros por ela 
estabelecidos. Além disso, é necessário que os produtores, principalmente os pequenos, se atualizem em relação às novas técnicas e equipamentos de amostragem e análises garantindo assim que a bebida chegue ao consumidor conforme as exigências da lei na disputa desse mercado em ascensão.

\subsection{Comparação entre cachaças envelhecidas após diversos tratamentos}

Os resultados obtidos ao longo de cinco amostragens em período de 390 dias de envelhecimento estão nas tabelas 6, 7, 8, 9 e 10. 
Tabela 6. Composição físico-química das cachaças com e sem irradiação, sem contato com a madeira

\begin{tabular}{|c|c|c|c|c|c|}
\hline \multirow{2}{*}{ Componentes } & \multirow{2}{*}{ Unidades } & \multicolumn{2}{|c|}{ Inicial } & \multicolumn{2}{|c|}{ Final (390 dias) } \\
\hline & & CNI & $\mathrm{CI}$ & CNI & $\mathrm{CI}$ \\
\hline Grau alcoólico & $\% \mathrm{v} / \mathrm{v} 20^{\circ} \mathrm{C}$ & 43,16 & 42,57 & 41,83 & 42,24 \\
\hline \multirow[t]{2}{*}{ Acidez volátil } & mg ác. acético/100mL etanol & & & & \\
\hline & $100 \%$ & 8,17 & 8,57 & 8,72 & 8,56 \\
\hline \multirow[t]{2}{*}{ Ésteres } & mg acetato de etila/100mL & & & & \\
\hline & etanol $100 \%$ & 7,50 & 7,84 & 8,80 & 8,85 \\
\hline \multirow[t]{2}{*}{ Aldeídos } & mg aldeído acético/100mL & & & & \\
\hline & etanol $100 \%$ & 12,63 & 14,87 & 14,79 & 15,09 \\
\hline Furfural & $\mathrm{mg} / 100 \mathrm{~mL}$ etanol $100 \%$ & 0,02 & 0,02 & 0,02 & 0,02 \\
\hline Isobutílico & $\mathrm{mg} / 100 \mathrm{~mL}$ etanol 100\% & 105,44 & 110,47 & 100,11 & 100,54 \\
\hline Isoamílico & $\mathrm{mg} / 100 \mathrm{~mL}$ etanol 100\% & 226,53 & 236,66 & 217,18 & 234,69 \\
\hline n-propílico & $\mathrm{mg} / 100 \mathrm{~mL}$ etanol $100 \%$ & 58,40 & 59,94 & 55,15 & 54,07 \\
\hline \multicolumn{6}{|l|}{ Álcoois } \\
\hline superiores & $\mathrm{mg} / 100 \mathrm{~mL}$ etanol $100 \%$ & 390,37 & 407,07 & 372,44 & 389,30 \\
\hline Congêneres & $\mathrm{mg} / 100 \mathrm{~mL}$ etanol $100 \%$ & 418,69 & 438,37 & 404,77 & 421,82 \\
\hline Álcool metílico & $\mathrm{mg} / 100 \mathrm{~mL}$ etanol 100\% & 6,48 & 7,40 & 5,30 & 6,91 \\
\hline Cobre & $\mathrm{mg} / \mathrm{L}$ & 2,44 & 2,44 & 2,42 & 2,74 \\
\hline Extrato seco & $\mathrm{g} / \mathrm{L}$ & 0,10 & 0,13 & 0,10 & 0,13 \\
\hline Cor & $\% \mathrm{~T}$ a $420 \mathrm{~nm}$ & 97,00 & 97,00 & 96,00 & 96,00 \\
\hline Tanino & $\mathrm{mg} / 100 \mathrm{~mL}$ & 0,65 & 0,65 & 0,66 & 0,66 \\
\hline
\end{tabular}

CN: Cachaça Não Irradiada; CI: Cachaça Irradiada 
Tabela 7. Composição físico-química da cachaça sob processo de envelhecimento em madeira carvalho sem irradiação

\begin{tabular}{|c|c|c|c|c|c|c|}
\hline \multirow{2}{*}{ Componentes } & \multirow{2}{*}{ Unidades } & \multicolumn{5}{|c|}{$\mathrm{CNI} / \mathrm{TNI}$} \\
\hline & & 76 dias & 147 dias & 228 dias & 314 dias & 390 dias \\
\hline Grau alcoólico & $\% \mathrm{v} / \mathrm{v} 20^{\circ} \mathrm{C}$ & 41,92 & 42,28 & 42,75 & 43,45 & 43,24 \\
\hline \multirow[t]{2}{*}{ Acidez volátil } & mg ác. acético/100mL & & & & & \\
\hline & etanol $100 \%$ & 30,86 & 38,94 & 57,77 & 64,96 & 83,14 \\
\hline \multirow[t]{3}{*}{ Ésteres } & mg acetato de & & & & & \\
\hline & etila/100mL etanol & & & & & \\
\hline & $100 \%$ & 13,07 & 12,90 & 13,88 & 20,04 & 19,02 \\
\hline \multirow[t]{3}{*}{ Aldeídos } & mg aldeído & & & & & \\
\hline & acético/100mL etanol & & & & & \\
\hline & $100 \%$ & 20,80 & 22,86 & 22,24 & 28,41 & 25,78 \\
\hline Furfural & $\mathrm{mg} / 100 \mathrm{~mL}$ etanol $100 \%$ & 0,71 & 0,66 & 0,94 & 0,96 & 1,14 \\
\hline Isobutílico & $\mathrm{mg} / 100 \mathrm{~mL}$ etanol $100 \%$ & 111,81 & 102,15 & 103,29 & 107,25 & 118,23 \\
\hline Isoamílico & $\mathrm{mg} / 100 \mathrm{~mL}$ etanol $100 \%$ & 239,72 & 225,34 & 229,34 & 240,05 & 266,48 \\
\hline n-propílico & $\mathrm{mg} / 100 \mathrm{~mL}$ etanol 100\% & 65,72 & 53,74 & 53,98 & 54,90 & 58,15 \\
\hline \multicolumn{7}{|l|}{ Álcoois } \\
\hline superiores & $\mathrm{mg} / 100 \mathrm{~mL}$ etanol $100 \%$ & 417,25 & 381,23 & 386,61 & 402,20 & 442,86 \\
\hline Congêneres & $\mathrm{mg} / 100 \mathrm{~mL}$ etanol 100\% & 482,69 & 456,59 & 481,44 & 516,57 & 571,94 \\
\hline Álcool metílico & $\mathrm{mg} / 100 \mathrm{~mL}$ etanol $100 \%$ & 9,95 & 6,22 & 7,93 & 5,93 & 8,83 \\
\hline Cobre & $\mathrm{mg} / \mathrm{L}$ & 1,58 & 1,86 & 1,86 & 1,86 & 1,86 \\
\hline Extrato seco & $\mathrm{g} / \mathrm{L}$ & 0,90 & 1,25 & 1,52 & 1,64 & 1,76 \\
\hline Cor & $\% \mathrm{~T}$ a $420 \mathrm{~nm}$ & 26,00 & 15,00 & 11,00 & 9,00 & 8,00 \\
\hline Tanino & $\mathrm{mg} / 100 \mathrm{~mL}$ & 45,01 & 60,79 & 66,06 & 72,04 & 80,91 \\
\hline
\end{tabular}

CNI / TNI: Cachaça Não Irradiada / Tonel Não Irradiado 
Tabela 8. Composição físico-química da cachaça sem irradiação sob processo de envelhecimento em madeira carvalho irradiada

\begin{tabular}{|c|c|c|c|c|c|c|}
\hline \multirow{2}{*}{ Componentes } & \multirow{2}{*}{ Unidades } & \multicolumn{5}{|c|}{$\mathrm{CNI} / \mathrm{TI}$} \\
\hline & & 76 dias & 147 dias & 228 dias & 314 dias & 390 dias \\
\hline Grau alcoólico & $\% \mathrm{v} / \mathrm{v} 20^{\circ} \mathrm{C}$ & 41,83 & 42,16 & 42,93 & 43,28 & 43,79 \\
\hline \multirow[t]{2}{*}{ Acidez volátil } & mg ác. acético/100mL & & & & & \\
\hline & etanol $100 \%$ & 28,11 & 36,82 & 52,05 & 73,36 & 93,99 \\
\hline \multirow[t]{3}{*}{ Ésteres } & mg acetato de & & & & & \\
\hline & etila/100mL etanol & & & & & \\
\hline & $100 \%$ & 11,88 & 10,46 & 12,61 & 17,36 & 15,45 \\
\hline \multirow[t]{3}{*}{ Aldeídos } & mg aldeído & & & & & \\
\hline & acético/100mL etanol & & & & & \\
\hline & $100 \%$ & 25,55 & 28,90 & 33,39 & 43,43 & 25,31 \\
\hline Furfural & $\mathrm{mg} / 100 \mathrm{~mL}$ etanol 100\% & 0,71 & 0,80 & 0,90 & 0,90 & 1,15 \\
\hline Isobutílico & $\mathrm{mg} / 100 \mathrm{~mL}$ etanol $100 \%$ & 109,55 & 103,88 & 103,12 & 106,93 & 115,67 \\
\hline Isoamílico & $\mathrm{mg} / 100 \mathrm{~mL}$ etanol $100 \%$ & 235,85 & 230,26 & 230,40 & 243,04 & 263,27 \\
\hline n-propílico & $\mathrm{mg} / 100 \mathrm{~mL}$ etanol 100\% & 59,81 & 54,40 & 53,65 & 53,85 & 56,75 \\
\hline \multicolumn{7}{|l|}{ Álcoois } \\
\hline superiores & $\mathrm{mg} / 100 \mathrm{~mL}$ etanol $100 \%$ & 405,21 & 388,54 & 387,17 & 403,82 & 435,69 \\
\hline Congêneres & $\mathrm{mg} / 100 \mathrm{~mL}$ etanol 100\% & 471,46 & 465,52 & 486,12 & 538,87 & 571,59 \\
\hline Álcool metílico & $\mathrm{mg} / 100 \mathrm{~mL}$ etanol $100 \%$ & 12,74 & 7,76 & 7,94 & 5,25 & 8,25 \\
\hline Cobre & $\mathrm{mg} / \mathrm{L}$ & 1,58 & 1,86 & 1,86 & 1,86 & 1,86 \\
\hline Extrato seco & $\mathrm{g} / \mathrm{L}$ & 0,05 & 1,28 & 1,54 & 1,66 & 1,80 \\
\hline Cor & $\% \mathrm{~T}$ a $420 \mathrm{~nm}$ & 24,00 & 13,00 & 9,00 & 8,00 & 6,00 \\
\hline Tanino & $\mathrm{mg} / 100 \mathrm{~mL}$ & 45,26 & 60,51 & 66,34 & 72,33 & 80,61 \\
\hline
\end{tabular}

CNI / TI: Cachaça Não Irradiada / Tonel Irradiado 
Tabela 9. Composição físico-química da cachaça irradiada sob processo de envelhecimento em madeira carvalho sem irradiação

\begin{tabular}{|c|c|c|c|c|c|c|}
\hline \multirow{2}{*}{ Componentes } & \multirow{2}{*}{ Unidades } & \multicolumn{5}{|c|}{ CI / TNI } \\
\hline & & 76 dias & 147 dias & 228 dias & 314 dias & 390 dias \\
\hline Grau alcoólico & $\% \mathrm{v} / \mathrm{v} 20^{\circ} \mathrm{C}$ & 41,92 & 42,28 & 42,93 & 43,28 & 43,79 \\
\hline \multirow[t]{2}{*}{ Acidez volátil } & mg ác. acético/100mL & & & & & \\
\hline & etanol $100 \%$ & 30,86 & 39,50 & 57,53 & 84,23 & 91,31 \\
\hline \multirow[t]{3}{*}{ Ésteres } & mg acetato de & & & & & \\
\hline & etila/100mL etanol & & & & & \\
\hline & $100 \%$ & 14,08 & 13,25 & 15,08 & 26,37 & 15,76 \\
\hline \multirow[t]{3}{*}{ Aldeídos } & mg aldeído & & & & & \\
\hline & acético/100mL etanol & & & & & \\
\hline & $100 \%$ & 21,57 & 22,64 & 24,61 & 33,58 & 41,35 \\
\hline Furfural & $\mathrm{mg} / 100 \mathrm{~mL}$ etanol 100\% & 0,83 & 0,85 & 0,90 & 1,01 & 1,09 \\
\hline Isobutílico & $\mathrm{mg} / 100 \mathrm{~mL}$ etanol $100 \%$ & 107,93 & 104,59 & 102,64 & 106,29 & 115,17 \\
\hline Isoamílico & $\mathrm{mg} / 100 \mathrm{~mL}$ etanol $100 \%$ & 231,45 & 231,29 & 228,92 & 235,23 & 261,65 \\
\hline n-propílico & $\mathrm{mg} / 100 \mathrm{~mL}$ etanol 100\% & 58,98 & 54,88 & 53,35 & 55,99 & 56,40 \\
\hline \multicolumn{7}{|l|}{ Álcoois } \\
\hline superiores & $\mathrm{mg} / 100 \mathrm{~mL}$ etanol $100 \%$ & 398,36 & 390,76 & 384,91 & 397,51 & 433,22 \\
\hline Congêneres & $\mathrm{mg} / 100 \mathrm{~mL}$ etanol 100\% & 465,70 & 467,00 & 483,03 & 542,70 & 582,73 \\
\hline Álcool metílico & $\mathrm{mg} / 100 \mathrm{~mL}$ etanol $100 \%$ & 6,16 & 7,48 & 7,81 & 9,35 & 7,21 \\
\hline Cobre & $\mathrm{mg} / \mathrm{L}$ & 1,58 & 1,29 & 1,29 & 1,29 & 1,29 \\
\hline Extrato seco & $\mathrm{g} / \mathrm{L}$ & 1,00 & 1,30 & 1,57 & 1,68 & 1,72 \\
\hline Cor & $\% \mathrm{~T}$ a $420 \mathrm{~nm}$ & 23,00 & 13,00 & 9,00 & 8,00 & 6,00 \\
\hline Tanino & $\mathrm{mg} / 100 \mathrm{~mL}$ & 47,55 & 63,55 & 69,17 & 77,91 & 87,04 \\
\hline
\end{tabular}

CI / TNI: Cachaça Irradiada / Tonel Não Irradiado 
Tabela 10. Composição físico-química da cachaça e da madeira carvalho com irradiação

\begin{tabular}{|c|c|c|c|c|c|c|}
\hline \multirow[t]{2}{*}{ Componentes } & \multirow{2}{*}{ Unidades } & \multicolumn{5}{|c|}{$\mathrm{CI} / \mathrm{TI}$} \\
\hline & & 76 dias & 147 dias & 228 dias & 314 dias & 390 dias \\
\hline Grau alcoólico & $\% \mathrm{v} / \mathrm{v} 20^{\circ} \mathrm{C}$ & 41,74 & 42,22 & 42,75 & 43,22 & 43,73 \\
\hline \multirow[t]{2}{*}{ Acidez volátil } & mg ác. acético/100mL & & & & & \\
\hline & etanol $100 \%$ & 27,85 & 36,63 & 53,12 & 97,14 & 101,65 \\
\hline \multirow[t]{3}{*}{ Ésteres } & mg acetato de & & & & & \\
\hline & etila/100mL etanol & & & & & \\
\hline & $100 \%$ & 12,83 & 11,03 & 14,22 & 23,56 & 11,61 \\
\hline \multirow[t]{3}{*}{ Aldeídos } & mg aldeído & & & & & \\
\hline & acético/100mL etanol & & & & & \\
\hline & $100 \%$ & 26,45 & 29,14 & 35,68 & 47,18 & 42,07 \\
\hline Furfural & $\mathrm{mg} / 100 \mathrm{~mL}$ etanol 100\% & 0,83 & 1,04 & 0,83 & 0,95 & 1,11 \\
\hline Isobutílico & $\mathrm{mg} / 100 \mathrm{~mL}$ etanol $100 \%$ & 106,54 & 107,77 & 102,55 & 105,68 & 112,77 \\
\hline Isoamílico & $\mathrm{mg} / 100 \mathrm{~mL}$ etanol $100 \%$ & 225,18 & 238,47 & 229,33 & 238,36 & 259,26 \\
\hline n-propílico & $\mathrm{mg} / 100 \mathrm{~mL}$ etanol $100 \%$ & 50,12 & 55,17 & 53,25 & 54,89 & 54,55 \\
\hline \multicolumn{7}{|l|}{ Álcoois } \\
\hline superiores & $\mathrm{mg} / 100 \mathrm{~mL}$ etanol $100 \%$ & 381,84 & 401,41 & 385,13 & 398,93 & 426,58 \\
\hline Congêneres & $\mathrm{mg} / 100 \mathrm{~mL}$ etanol $100 \%$ & 449,80 & 479,25 & 488,98 & 567,76 & 583,02 \\
\hline Álcool metílico & $\mathrm{mg} / 100 \mathrm{~mL}$ etanol $100 \%$ & 10,41 & 8,81 & 7,84 & 9,07 & 6,84 \\
\hline Cobre & $\mathrm{mg} / \mathrm{L}$ & 1,58 & 1,31 & 1,29 & 1,31 & 1,31 \\
\hline Extrato seco & $g / L$ & 0,10 & 1,32 & 1,59 & 1,71 & 1,77 \\
\hline Cor & $\% \mathrm{~T} \mathrm{a} 420 \mathrm{~nm}$ & 22,00 & 12,00 & 7,00 & 7,00 & 5,00 \\
\hline Tanino & $\mathrm{mg} / 100 \mathrm{~mL}$ & 47,91 & 63,47 & 69,41 & 78,14 & 86,87 \\
\hline
\end{tabular}

CI / TI: Cachaça Irradiada / Tonel Irradiado

Os resultados das análises físico-químicas e cromatográficas submetidos à análise estatística pelo teste de Tukey ao nível de 5\% mostraram que não foram estatisticamente significativos as variações de grau alcoólico, acidez volátil, ésteres, furfural, álcoois superiores, congêneres, extrato seco e álcool metílico encontradas no período. Ou seja, nem os tratamentos nas aguardentes (irradiada e não irradiada) e nem estes mesmos tratamentos nos tonéis, não produziram efeitos diretos sobre esses componentes. 
A fim de facilitar a discussão, os parâmetros obtidos nas análises físico-químicas foram separados em função dos componentes em estudo.

\subsubsection{Grau Alcoólico}

O grau alcoólico de uma cachaça armazenada ou em envelhecimento em tonéis de madeira pode sofrer oscilações em função de temperatura, como nas regiões de baixas latitudes onde o intervalo é pequeno, constantemente entre $25-32^{\circ} \mathrm{C}$. A umidade relativa alta, de 70 a 90\% em boa parte do ano, também pode ser favorável ao envelhecimento mais rápido, entretanto com perdas variáveis em função da flutuação. No Brasil são comuns perdas de álcool em torno de $3 \%$ a $4 \%$ ao ano, seja pela qualidade dos tonéis utilizados, seja pela idade das madeiras em uso.

Em verdade, as regiões mais adequadas para a canavicultura são aquelas que apresentam solos e climas sem restrições de fertilidade ou térmicas. Invernos secos e frios e verões úmidos e quentes são aqueles que se verificam na região sudeste, parte da centroeste e faixa da zona da mata do nordeste. Embora baixa umidade relativa possa favorecer perda de água enquanto alta umidade favoreça perda de álcool dos tonéis (Nicol, 2003), as perdas ao longo do ano e das variações climáticas parecem não ser exatamente proporcionais a esses fatores, mas dependem de vários outros como dilatação e contração da cachaça dentro do tonel, vazamentos e expulsão de cachaça por frestas e conseqüente aspiração de ar por contração no resfriamento em ocorrências sucessivas, devido à inadequação de instalações e de ambientes, além do modo de armazenamento.

Com freqüência de observa ainda que amostras coletadas nos tonéis de armazenamento mostram diferentes teores alcoólicos em diferentes alturas de coleta. Ao longo de todo dia variam temperatura e densidade. Por isso, há necessidade de amostradores especiais como de coleta de álcool etílico, que amostram ao longo de toda a altura para que seja representativa do verdadeiro conteúdo médio do tanque. Na falta de homogeneização do tanque, a amostragem deve ser tal que minimize os desvios.

Há ainda o erro inerente ao processo de medida do teor alcoólico qualquer que seja a metodologia aplicada. Em particular, a metodologia aplicada no presente trabalho 
admite a interferência crescente dos congêneres extraídos da madeira e os resultantes das reações ao longo de todo o período de envelhecimento. Ainda assim, os resultados obtidos ao longo de cinco amostragens em período de 390 dias de envelhecimento e submetidos a análise estatística pelo teste de Tukey ao nível de 5\% mostrou que não foram significativas as variações entre as médias do período (Tabela 11). Ou seja, nem os tratamentos nas cachaças (irradiada e não irradiada) e nem estes mesmos tratamentos nos tonéis, não produziram efeitos diretos sobre o grau alcoólico.

Tabela 11. Médias dos tratamentos que a cachaça foi submetida durante o período total de envelhecimento para grau alcoólico

\begin{tabular}{ll}
\hline \multicolumn{1}{c}{ Tratamentos } & Grau alcoólico \\
\hline Cachaça não irradiada x Tonel não irradiado & $42,73^{\text {a }}$ \\
Cachaça não irradiada x Tonel irradiado & $42,84^{\text {a }}$ \\
Cachaça irradiada x Tonel não irradiado & $42,80^{\text {a }}$ \\
Cachaça irradiada x Tonel não irradiado & $42,73^{\text {a }}$ \\
\hline
\end{tabular}

Médias seguidas pela mesma letra não diferem pelo teste de Tukey a 5\%

\subsubsection{Acidez}

Na legislação de cachaça, um ponto que causa constante discussão entre técnicos se refere aos teores de acidez volátil e seu limite máximo. Freqüentemente, um destilado com teor elevado de acidez volátil é reflexo de um processo fermentativo mal conduzido onde matéria prima e fermento não se encontraram em condições favoráveis de processamento. Também a condução da destilação pode acarretar cachaça com acidez elevada e o reflexo natural é de um produto final de pouca qualidade.

Entretanto, na legislação esses teores são mantidos elevados não visando salvaguardar a cachaça recém destilada de má qualidade, mas certamente a envelhecida cujo teor aumenta com o tempo de envelhecimento em função da oxidação de etanol com formação de ácido acético e acetaldeído (Reazin, 1981; Litchev, 1989). Desse modo, uma cachaça de baixa acidez inicial pode revelar seu grau de maturação pelo aumento da 
acidez volátil que, todavia, não desqualifica o produto no aspecto sensorial pelo conjunto agradável que forma com outros componentes.

Neste trabalho, não houve diferença significativa ao nível de 5\% entre os tratamentos para o componente acidez, como mostra a tabela 12.

Tabela 12. Médias dos tratamentos que a cachaça foi submetida durante o período total de envelhecimento para acidez volátil

\begin{tabular}{lc}
\hline \multicolumn{1}{c}{ Tratamentos } & Acidez Volátil \\
\hline Cachaça não irradiada / Tonel não irradiado & $63,28^{\text {a }}$ \\
Cachaça não irradiada / Tonel irradiado & $60,69^{\text {a }}$ \\
Cachaça irradiada / Tonel não irradiado & $60,69^{\text {a }}$ \\
Cachaça irradiada / Tonel não irradiado & $56,87^{\text {a }}$ \\
\hline
\end{tabular}

Médias seguidas pela mesma letra não diferem pelo teste de Tukey a 5\%

\subsection{3 Ésteres}

Tem sido estabelecido que as bebidas destiladas congenéricas como brandy, whisky, rum e cachaça possuem componentes comuns apesar de serem produtos de diferentes matérias primas. O principal denominador comum é a ação das leveduras sobre os açúcares, entretanto cada destilado tem sua própria característica sensorial que a legislação e a literatura tratam-na como peculiar ao produto (Brasil, 2005; Lehtonen \& Suomalainen, 1977 citados por Nicol, 2003).

Os ésteres são produzidos durante a fermentação pelas leveduras e também pela esterificação de ácidos graxos com etanol, sendo o acetato de etila o componente majoritário deste grupo (Faria et al., 2003) e responsável pelo odor agradável das bebidas envelhecidas (Litchev, 1989).

Nos tratamentos utilizados neste ensaio, mostrados na tabela 13, não houve diferença estatística entre eles, evidenciando que os fatores estudados não influenciaram nas reações de sua formação. 
Tabela 13. Médias dos tratamentos que a cachaça foi submetida durante o período total de envelhecimento para ésteres

\begin{tabular}{ll}
\hline \multicolumn{1}{c}{ Tratamentos } & Ésteres \\
\hline Cachaça não irradiada / Tonel não irradiado & $15,78^{\mathrm{a}}$ \\
Cachaça não irradiada / Tonel irradiado & $13,55^{\mathrm{a}}$ \\
Cachaça irradiada / Tonel não irradiado & $16,91^{\mathrm{a}}$ \\
Cachaça irradiada / Tonel não irradiado & $14,65^{\mathrm{a}}$ \\
\hline
\end{tabular}

Médias seguidas pela mesma letra não diferem pelo teste de Tukey a 5\%

\subsubsection{Aldeídos}

Uma das reações químicas mais importantes durante a maturação que altera os componentes do destilado é a oxidação e formação de acetal. Exemplos de oxidação são a formação de acetaldeído e ácido acético a partir do álcool etílico (Reazin, 1981) e a formação de dimetilsulfóxido a partir de dimetilsulfeto (Fujii et al., 1992 citados por Piggott \& Conner, 2003).

Os equilíbrios entre acetal e acetaldeído são estabelecidos também para muitos aldeídos e são particularmente importantes para um aroma específico, pois aldeídos freqüentemente têm odor desagradável e pungente enquanto os acetais são agradáveis e frutados (Perry, 1989 citado por Piggott \& Conner, 2003). O acetaldeído tem características de odor reportadas como "refrescante”, “frutado” e "verde”, contribuindo assim para o aroma final de cachaça, tanto pela redução do odor pungente desse aldeído majoritário na bebida quanto pelo provimento das características de aroma citadas (Nóbrega, 2003).

O equilíbrio entre aldeídos livres, hemi-acetal e acetal é influenciado pelo $\mathrm{pH}$ e a concentração de álcool etílico, segundo Perry (1986) citado por Piggott \& Conner (2003), e também é parcialmente influenciado pelo tipo de madeira do tonel.

No presente caso (Tabela 14), mostra que houve diferença estatística entre os tratamentos, havendo maior teor de aldeídos nos tonéis que foram irradiados 
possivelmente pela aceleração e exposição de maior superfície de contato nestes tonéis do que nas cachaças irradiadas ou não irradiadas em tonéis não irradiados.

Assim, estes fatos poderiam colaborar para abreviar tempo de maturação ou envelhecimento em conjunto com o aumento da intensidade de cor como já foi discutido anteriormente.

Tabela 14. Médias dos tratamentos que a cachaça foi submetida durante o período total de envelhecimento para aldeídos

\begin{tabular}{ll}
\hline \multicolumn{1}{c}{ Tratamentos } & Aldeídos \\
\hline Cachaça não irradiada / Tonel não irradiado & $24,20^{\mathrm{b}}$ \\
Cachaça não irradiada / Tonel irradiado & $31,32^{\mathrm{a}}$ \\
Cachaça irradiada / Tonel não irradiado & $28,75^{\mathrm{a}}$ \\
Cachaça irradiada / Tonel não irradiado & $36,10^{\mathrm{a}}$ \\
\hline
\end{tabular}

Médias seguidas pela mesma letra não diferem pelo teste de Tukey a 5\%

\subsubsection{Furfural}

Na nova Instrução Normativa para a fixação de padrões de identidade e qualidade para aguardente de cana e para cachaça (Brasil, 2005), o item furfural foi desdobrado para furfural e hidroximetilfurfural, sendo mantido o teor máximo em $5 \mathrm{mg} 100 \mathrm{ml}^{-1}$ de álcool anidro. Estes compostos são principalmente formados durante a destilação a partir de pentoses, surgindo predominantemente como produto de cauda em alambiques dependendo do tipo de aquecimento (Faria et al., 2003).

Observa-se que na tabela 15 , os teores de furfural não diferiram estatisticamente em função dos tratamentos na cachaça, na irradiação ou não da madeira e tampouco em função do tempo de envelhecimento, ao menos até 390 dias, tempo considerado fim do experimento. Realmente o componente comportou-se como produto da destilação não sofrendo reações com o tempo, ao contrário do observado por Egorov \& Rodopulo (1994) que considerou oriundo das pentoses da madeira do tonel. 
Tabela 15. Médias dos tratamentos que a cachaça foi submetida durante o período total de envelhecimento para furfural

\begin{tabular}{lc}
\hline \multicolumn{1}{c}{ Tratamentos } & Furfural \\
\hline Cachaça não irradiada / Tonel não irradiado & $0,88^{\text {a }}$ \\
Cachaça não irradiada / Tonel irradiado & $0,89^{\text {a }}$ \\
Cachaça irradiada / Tonel não irradiado & $0,94^{\text {a }}$ \\
Cachaça irradiada / Tonel não irradiado & $0,95^{\text {a }}$ \\
\hline
\end{tabular}

Médias seguidas pela mesma letra não diferem pelo teste de Tukey a 5\%

\subsection{6 Álcoois Superiores}

Os álcoois superiores são produtos metabólicos decorrentes de crescimento de leveduras e aproveitamento de aminoácidos como fonte de nutrientes amoniacais. Dependem grandemente das condições do meio de fermentação, da quantidade e viabilidade do inoculo, da temperatura, do teor alcoólico final do vinho, entre outros fatores. Dependendo do equipamento e do processo de destilação, o teor no produto final pode variar bastante, tendendo a acumular até oito vezes o teor no vinho. (Leauté, 1990).

No caso presente, os álcoois superiores foram analisados separadamente como, isobutílico, isoamílico e n-propílico através de análise cromatográfica já dentro da metodologia exigida pela nova Instrução Normativa de 2005.

A tabela 16, referente ao teste de Tukey a 5\%, mostrou que não houve diferença nos teores destes componentes em função dos tratamentos e dos tempos de envelhecimento.

Assim, pode-se assumir que a irradiação não alterou o teor de álcoois superiores na cachaça e que tampouco a madeira do tonel tenha influenciado em alteração de teor por qualquer tipo de mecanismo de reação à absorção ou adsorção. 
Tabela 16. Médias dos tratamentos que a cachaça foi submetida durante o período total de envelhecimento para álcoois superiores individualmente e para a sua soma

\begin{tabular}{lcccc}
\hline \multicolumn{1}{c}{ Tratamentos } & A1 & A2 & A3 & SA \\
\hline Cachaça não irradiada / Tonel não irradiado & $108,54^{\text {a }}$ & $240,19^{\text {a }}$ & $57,30^{\text {a }}$ & $406,03^{\text {a }}$ \\
Cachaça não irradiada / Tonel irradiado & $107,84^{\text {a }}$ & $240,56^{\text {a }}$ & $55,69^{\text {a }}$ & $404,09^{\text {a }}$ \\
Cachaça irradiada / Tonel não irradiado & $107,32^{\text {a }}$ & $237,71^{\text {a }}$ & $55,92^{\text {a }}$ & $400,95^{\text {a }}$ \\
Cachaça irradiada / Tonel não irradiado & 107,06 $^{\text {a }}$ & $238,12^{\text {a }}$ & $53,60^{\text {a }}$ & $398,78^{\text {a }}$
\end{tabular}

Médias seguidas pela mesma letra não diferem pelo teste de Tukey a 5\%

A1: álcool isobutílico, A2: álcool isoamílico, A3: álcool n-propílico, SA: A1+A2+A3

\subsubsection{Coeficiente de Congêneres}

O coeficiente de congêneres (componentes voláteis "não álcool” ou substâncias voláteis “não álcool” ou componentes secundários "não álcool” ou impurezas voláteis “não álcool”) é a soma de acidez volátil (expressa em ácido acético), aldeídos (expressos em acetaldeído), ésteres totais (expressos em acetato de etila), álcoois superiores (expressos pela soma do álcool n-propílico, álcool isobutílico e álcoois isoamílicos), furfural e hidroximetilfurfural. O coeficiente de congêneres não poderá ser superior a 650 mg por 100 mL de álcool anidro, segundo Instrução Normativa ${ }^{\circ}$ 13, de 29 de junho de 2005.

Como todos os componentes dos congêneres individualmente não mostraram diferenças significativas pelo teste de Tukey, a somatória de todos os congêneres, por óbvio, não apresenta diferença significativa entre os tratamentos dentro dos tempos estudados (Tabela 17). 
Tabela 17. Médias dos tratamentos que a cachaça foi submetida durante o período total de envelhecimento para coeficiente de congêneres

\begin{tabular}{lc}
\hline \multicolumn{1}{c}{ Tratamentos } & Coeficiente de Congêneres \\
\hline Cachaça não irradiada x Tonel não irradiado & $501,85^{\text {a }}$ \\
Cachaça não irradiada x Tonel irradiado & $506,71^{\text {a }}$ \\
Cachaça irradiada x Tonel não irradiado & $508,23^{\text {a }}$ \\
Cachaça irradiada x Tonel não irradiado & $513,76^{\text {a }}$ \\
\hline
\end{tabular}

Médias seguidas pela mesma letra não diferem pelo teste de Tukey a 5\%

\subsection{8 Álcool metílico}

Álcool metílico em vinho e por conseqüência em destilados tem origem na hidrólise de matérias pécticas. Como o teor de matérias pécticas em cana-de-açúcar é muito baixo, um dos menores componentes orgânicos dos não açúcares (Horii, 2004), por conseguinte, o teor de álcool metílico foi também sempre muito baixo, não se comparando aos destilados de frutas, geralmente com altos teores de pectina.

A cachaça utilizada neste ensaio apresentou uma média de $8 \mathrm{mg}$ de álcool metílico por $100 \mathrm{~mL}$ de álcool anidro e este valor não sofre alteração significativa pelo teste de Tukey, em entre os tratamentos nem ao longo do período de envelhecimento (Tabela 18).

Tabela 18. Médias dos tratamentos que a cachaça foi submetida durante o período total de envelhecimento para álcool metílico

\begin{tabular}{lc}
\hline \multicolumn{1}{c}{ Tratamentos } & Álcool metílico \\
\hline Cachaça não irradiada x Tonel não irradiado & $7,77^{\mathrm{a}}$ \\
Cachaça não irradiada x Tonel irradiado & $8,39^{\mathrm{a}}$ \\
Cachaça irradiada x Tonel não irradiado & $7,60^{\mathrm{a}}$ \\
Cachaça irradiada x Tonel não irradiado & $8,59^{\mathrm{a}}$ \\
\hline
\end{tabular}

Médias seguidas pela mesma letra não diferem pelo teste de Tukey a 5\% 


\subsubsection{Cobre}

O teor de cobre na cachaça ensaiada também foi submetido ao teste de Tukey e foi observado que a cachaça não irradiada diferiu da cachaça irradiada, independente de ter sido o tonel irradiado ou não, como mostrado na tabela 19.

Novamente, no presente caso, fica aberta a polêmica se independentemente dos tratamentos, os tonéis absorveram ou adsorveram mais cobre, ou compostos fenólicos como taninos reagiram produzindo mais cor, pois no item cor os tratamentos que apresentaram menor transmitância e, portanto maior intensidade de cor, também apresentaram menores teores médios de cobre e maiores teores médios de tanino. Estes resultados são merecedores de estudos mais intensivos.

Tabela 19. Médias dos tratamentos que a cachaça foi submetida durante o período total de envelhecimento para cobre

\begin{tabular}{ll}
\hline \multicolumn{1}{c}{ Tratamentos } & Cobre \\
\hline Cachaça não irradiada x Tonel não irradiado & $1,80^{\mathrm{a}}$ \\
Cachaça não irradiada x Tonel irradiado & $1,80^{\mathrm{a}}$ \\
Cachaça irradiada x Tonel não irradiado & $1,35^{\mathrm{b}}$ \\
Cachaça irradiada x Tonel não irradiado & $1,36^{\mathrm{b}}$ \\
\hline
\end{tabular}

Médias seguidas pela mesma letra não diferem pelo teste de Tukey a 5\%

\subsubsection{Extrato Seco}

Os extratos de madeira diferem para as variedades de carvalho usadas nos tonéis para maturação ou envelhecimento de bebidas. Em geral, carvalho europeu produz extrato mais concentrado em taninos do que em lactonas e escopoletina que carvalho americano. Entretanto, somente isso não justifica a diferença sensorial que se observa em whiskies envelhecidos nas duas madeiras. Há ainda a se considerar que a composição do extrato depende não só da espécie, mas também da idade, do pré-tratamento submetido 
antes da utilização, do número de vezes que foi utilizado, entre outros fatores (Maga, 1989; Reazin, 1981 citados por Piggott \& Conner, 2003).

Durante o envelhecimento, o aumento de extrato fenólico ocorre devido à degradação da lignina em compostos aromáticos como a vanilina, siringaldeído, coniferaldeído e sinapaldeído (Reazin, 1983; Nishimura et al., 1983 citados por Piggott \& Conner, 2003). Além da extração destes compostos pelo álcool etílico ocorrem ainda alterações na lignina em decorrência de oxidações e hidrólise ou etanólise, e essas características determinam denominações como "vanila”, “adocicado”, “amadeirado”, segundo Piggott et al (1993a) citados por Piggott \& Conner (2003).

Analisando-se individualmente o item extrato seco (Tabela 20), a expectativa é que ela seja proporcional à extração de compostos fenólicos e de cor. Entretanto, tratando-se de massa extraída e cor, é bem possível que os resultados obtidos não apresentem significância como realmente ocorreu.

Tabela 20. Médias dos tratamentos que a cachaça foi submetida durante o período total de envelhecimento para extrato seco

\begin{tabular}{lc}
\hline \multicolumn{1}{c}{ Tratamentos } & Extrato seco \\
\hline Cachaça não irradiada x Tonel não irradiado & $1,41^{\mathrm{a}}$ \\
Cachaça não irradiada x Tonel irradiado & $1,27^{\mathrm{a}}$ \\
Cachaça irradiada x Tonel não irradiado & $1,45^{\mathrm{a}}$ \\
Cachaça irradiada x Tonel não irradiado & $1,30^{\mathrm{a}}$ \\
\hline
\end{tabular}

Médias seguidas pela mesma letra não diferem pelo teste de Tukey a 5\%

\subsubsection{Cor}

A coloração adquirida pela cachaça em envelhecimento em madeira carvalho e função, entre outros fatores, da classificação botânica e origem do carvalho que compõe o tonel, dos tratamentos sofridos antes do primeiro uso, do tamanho ou volume do tonel, que interfere diretamente no tempo de envelhecimento, da existência de defeitos na 
madeira, da absorção de componentes adversos à qualidade organoléptica desejada ou mesmo da presença de contaminantes de usos anteriores.

No presente caso, os tonéis foram fabricados com madeira de origem desconhecida, com 20 litros de capacidade cada, sem tratamento prévio como queima, e apenas testes com água para vedação da madeira.

Como em qualquer teste de envelhecimento em madeira, a coloração da cachaça ao longo do tempo tornou-se amarelada pela extração de compostos principalmente taninos e suas reações de oxidação, segundo Singleton (1995) maior responsável pelo progressivo escurecimento ou intensificação da cor amarelo-alaranjado.

O aumento progressivo da coloração, medida pela redução da transmitância ao longo do envelhecimento (390 dias), revelou que cachaça irradiada em tonel irradiado apresentou a menor transmitância ou maior intensidade de cor (Tabela 21). Isso ocorreu devido a maior extração de componentes seja pela ação da irradiação sobre a madeira aumentando sua porosidade e, portanto, superfície de contato (Vitti et al., 1998), seja pela ação de irradiação sobre os extratos do carvalho. Nesse aspecto, existe a particular vantagem da redução no tempo de envelhecimento pela maior superfície de contato e pela maior extração, mas também a desvantagem da perda de características da madeira ou redução da vida útil do tonel, encarecendo o produto final. Há, portanto, que se estudar a otimização desse processo.

Tabela 21. Médias dos tratamentos que a cachaça foi submetida durante o período total de envelhecimento para cor

\begin{tabular}{ll}
\hline \multicolumn{1}{c}{ Tratamentos } & Cor \\
\hline Cachaça não irradiada x Tonel não irradiado & $13,80^{\mathrm{a}}$ \\
Cachaça não irradiada x Tonel irradiado & $12,00^{\mathrm{b}}$ \\
Cachaça irradiada x Tonel não irradiado & $11,80^{\mathrm{b}}$ \\
Cachaça irradiada x Tonel não irradiado & $10,60^{\mathrm{c}}$ \\
\hline
\end{tabular}




\subsubsection{Taninos}

Deve ser considerada no envelhecimento, a razão superfície/volume. Menores tonéis têm maiores relações superfície para volume e conseqüentemente resultam em maior rapidez de extração de componentes, mas também maiores taxas de evaporação de álcool etílico e de água. Para uma mesma madeira e um mesmo histórico, em tonéis menores são esperadas produções maiores de extratos e envelhecem whiskies em menos tempo, segundo Philp, (1989) citado por Piggott \& Conner (2003).

No presente caso, as cachaças irradiadas apresentaram maiores teores de taninos, diferindo estatisticamente das não irradiadas (Tabela 22), o que poderia levar à interpretação de que a irradiação teria, de alguma forma, influenciado a extração de compostos fenólicos ou degradado maior quantidade de lignina, por exemplo. Por outro lado, como o pareamento dos tonéis se deu entre um irradiado e outro não irradiado, nos dois grupos, pode-se admitir que a falta de histórico das madeiras dos tonéis possam provocar tal situação e que somente um elevado número de repetições poderia diminuir tais dúvidas, já que para outros componentes não ocorreu essa diferenciação salvo em relação à.cor, que os tratamentos coincidem.

Tabela 22. Médias dos tratamentos que a cachaça foi submetida durante o período total de envelhecimento para taninos

\begin{tabular}{ll}
\hline \multicolumn{1}{c}{ Tratamentos } & Taninos \\
\hline Cachaça não irradiada x Tonel não irradiado & $64,96^{\mathrm{b}}$ \\
Cachaça não irradiada x Tonel irradiado & $65,01^{\mathrm{b}}$ \\
Cachaça irradiada x Tonel não irradiado & $69,04^{\mathrm{a}}$ \\
Cachaça irradiada x Tonel não irradiado & $69,16^{\mathrm{a}}$ \\
\hline
\end{tabular}

Médias seguidas pela mesma letra não diferem pelo teste de Tukey a 5\% 


\subsection{Análise sensorial}

Os resultados da análise sensorial das cachaças submetidas aos 6 tratamentos mencionados estão na tabela 23.

Tabela 23. Média das notas atribuídas pelos provadores aos parâmetros sensoriais

\begin{tabular}{lccc}
\hline \multicolumn{1}{c}{ Tratamentos } & Aroma & Sabor & Aparência \\
\hline Cachaça não irradiada & $5,633^{\mathrm{b}}$ & $4,900^{\mathrm{b}}$ & $5,767^{\mathrm{b}}$ \\
Cachaça irradiada & $6,300^{\mathrm{a}}$ & $5,267^{\mathrm{a}}$ & $6,100^{\mathrm{a}}$ \\
Cachaça não irradiada x tonel não irradiado & $6,133^{\mathrm{a}}$ & $5,200^{\mathrm{a}}$ & $6,233^{\mathrm{a}}$ \\
Cachaça não irradiada x tonel irradiado $_{\text {Cachaça irradiada x tonel não irradiado }}^{6,767^{\mathrm{a}}}$ & $5,300^{\mathrm{a}}$ & $6,700^{\mathrm{a}}$ \\
Cachaça Irradiada x tonel irradiado & $6,600^{\mathrm{a}}$ & $5,300^{\mathrm{a}}$ & $6,567^{\mathrm{a}}$ \\
\hline
\end{tabular}

Letras diferentes na vertical indicam diferença estatística entre os tratamentos pelo teste de Tukey, ao nível de 5\%

Os testes afetivos são utilizados quando se necessita conhecer o quanto o consumidor gosta ou desgosta do produto, e para isso se utiliza escala hedônica. Dos valores relativos de aceitabilidade se pode inferir a preferência, ou seja, as amostras mais aceitas são as mais preferidas e vice-versa (Meilgaard et al., 1991).

Em relação à cachaça não irradiada e não envelhecida, as cachaças submetidas aos outros tratamentos apresentaram maior aceitabilidade por parte dos provadores para todos os parâmetros analisados sensorialmente (aroma, sabor e aparência).

A cachaça irradiada e as envelhecidas nos tonéis (irradiados ou não) não apresentaram diferença significativa em nenhum dos parâmetros sensoriais analisados. Isso pode ter acontecido devido à heterogeneidade entre os provadores, já que a análise sensorial indicou diferença estatística significativa entre eles (Fcalc>Ftab) (Tabela 24). Vale lembrar que os provadores não eram treinados. 
Tabela 24. Valores de F da análise de variância para a variável "provadores”

\begin{tabular}{lcc}
\hline & Atributos & F provadores \\
\hline Aroma & 2,622 \\
Sabor & 3,719 \\
Aparência & 2,561 \\
\hline
\end{tabular}

F tabelado $=2,455$ 


\section{CONCLUSÕES}

Em relação aos padrões de identidade e qualidade para a aguardente de cana e para cachaça estabelecidos em Brasil (2005), 45 (48\% do total) encontraram-se não conformes em pelo menos um dos componentes analisados. A cachaça não apresenta padronização da bebida, pois foi observada uma grande variabilidade na concentração dos componentes da bebida entre as marcas analisadas. Isso reflete as dificuldades enfrentadas pelos produtores de garantir a qualidade físico-química e a padronização da bebida em todas as etapas da produção. Além disso, a utilização de técnicas obsoletas de amostragem e equipamentos pouco precisos pode resultar em análises fora das especificações legais, dificultando o crescimento do mercado interno e impossibilitando as exportações.

A irradiação da cachaça e do tonel não alterou a maioria dos componentes voláteis do coeficiente de congêneres como acidez volátil, ésteres, álcoois superiores e furfural durante um período de envelhecimento de 390 dias. Há evidências, entretanto, que os parâmetros de alguns componentes como aldeídos, taninos, cor e teor de cobre são de alguma forma influenciados, resultando em aceleração parcial do processo de maturação ou envelhecimento.

A aceleração do processo de envelhecimento foi confirmada pela avaliação sensorial, onde a cachaça e/ou tonel irradiados receberam maior indicação de aprovação em todos os parâmetros analisados (aroma, sabor e aparência). 


\section{REFERÊNCIAS BIBLIOGRÁFICAS}

ANDRADE, L.A. de B. Cultura da cana-de-açúcar. In: CARDOSO, M. das G. (Ed.) Produção de cachaça de cana. Lavras: Editora UFLA, 2001. cap.1, p.19-50.

ANDRADE-SOBRINHO, L.G de; BOSCOLO, M.; LIMA-NETO, B. dos S.; FRANCO, D.W. Carbamato de etila em bebidas alcoólicas (cachaça, tiquira, uísque e grapa). Química Nova, v.25, n.6b, p.1074-1077, nov./dez. 2002.

ASSOCIATION OF OFFICIAL ANALYTICAL CHEMISTS. Official methods of analysis of the association of official analytical chemists. 16.ed. Washington, 1995. v.2.

BOSCOLO, M.; LIMA NETO, B.S.; FRANCO, D.W. O envelhecimento de aguardente de cana-de-açúcar em tonéis de madeira. Engarrafador Moderno, v.6, n.41, p.3033, set./out. 1995.

BOZA, Y.E.A.G. Influência da condução da destilação sobre a composição e a qualidade sensorial da aguardente de cana. Piracicaba, 1996. 143p. Dissertação (Mestrado)- Escola Superior de Agricultura “Luiz de Queiroz”, Universidade de São Paulo.

BOZA, Y.; OETTERER, M. Envelhecimento de cachaça de cana. Boletim da Sociedade Brasileira de Ciência e Tecnologia de Alimentos, v.33, n.1, p.8-15, 1999. 
BRASIL. Leis, decretos, etc. Portaria $n^{0} 371$ de 18 de setembro de 1974. Diário Oficial da União, Brasília, 19 de setembro de 1974.

BRASIL. Leis, decretos, etc. Portaria nํㅜ 076 de 27 de novembro de 1986. Diário Oficial da União, Brasília, 03 de dezembro de 1986.

BRASIL. Leis, decretos, etc. Decreto $\mathrm{n}^{0} 2.314$ de 04 de setembro de 1997. Diário Oficial da União, Brasília, 05 de setembro de 1997a.

BRASIL. Leis, decretos, etc. Portaria nº 40 de 20 de janeiro de 1997. Diário Oficial da União, Brasília, 21 de janeiro de 1997b.

BRASIL. Leis, decretos, etc. Decreto nº 4.062 de 21 de dezembro de 2001. Diário Oficial da União. Brasília, 21 de dezembro de 2001.

BRASIL. Leis, decretos, etc. Decreto nํㅜ 4.072 de 03 de janeiro de 2002. Diário Oficial da União, Brasília, 04 de janeiro de 2002.

BRASIL. Leis, decretos, etc. Instrução Normativa $n^{0} 13$ de 29 de junho de 2005. Diário Oficial da União. Brasília, 30 de junho de 2005b.

BRASIL. Ministério do Desenvolvimento, Indústria e Comércio Exterior. http://aliceweb.desenvolvimento.gov.br/consulta_nova/consulta.asp?tip_consulta=Im pNCM\&titulo_p=Importação\%20Brasileira\&titulo_s=1996\%20a\%202005. (12 jul 2005a).

CARDELLO, H.M.A.B.; FARIA, J.B. Modificações físico-químicas e sensoriais de cachaça de cana durante o envelhecimento em tonel de carvalho (Quercus alba L.). Boletim do Centro de Pesquisa e Processamento de Alimentos, v.15, n.2, p.87100, 1997. 
CARDELLO, H.M.A.B.; FARIA, J.B. Análise tempo-intensidade de características sensoriais de cachaça de cana durante o envelhecimento em tonel de carvalho (Quercus sp). Boletim da Sociedade Brasileira de Ciência e Tecnologia de Alimentos, v.33, n.1, p.27-34, jan./abr. 1999.

CARDOSO, M. das G. Análises físico-químicas de aguardente. In: CARDOSO, M. das G. (Ed.) Produção de aguardente de cana-de-açúcar. Lavras: Editora UFLA, 2001. cap. 5. p.152-173.

CASEMIRO, A.R.S.de; CAMPOS, J.O.S. Importância dos barris de madeira no envelhecimento da cachaça. Engarrafador Moderno, v.10, n.72, p.50-52, fev. 2000.

CLYNE, J.C., CONNER, J.M., PATERSON, A., PIGGOTT, J.R. The effect of cask charring on Scotch whisky maturation. International Journal of Food Science and Technology, v.28, p.69-81, 1993.

DIAS, S.M.B.C. Efeitos de diferentes tipos de madeira sobre a composição química da cachaça de cana envelhecida. Belo Horizonte, 1997. 109p. Dissertação (Mestrado) Faculdade de Farmácia, Universidade Federal de Minas Gerais.

DRINKS INTERNATIONAL. Major export drive for world's "biggest Brand", 1994. p.40.

EVANGELISTA, A.R. Aproveitamento de resíduos da fabricação da aguardente. In: CARDOSO, M. das G. (Ed.) Produção de aguardente de cana-de-açúcar. Lavras: Editora UFLA, 2001. cap. 4, p.128-151.

EGOROV, I.A.; RODOPULO, A.K. Investigation of aroma-forming substances In cognac spirits In their aging process. Applied Biochemistry and Microbiology, v.30, n.4/5, p.539-542, 1994. 
FARIA, J.B.; LOYOLA, E.; LÓPEZ, M.G.; DUFOUR, J.P. Cachaça, Pisco e Tequila. In: LEA, A.G.H.; PIGGOTT, J.R. (Eds.) Fermented beverage production. 2 ed. New York: Klumer Academic/Plenum Publishers, 2003. cap.15, p.335-363.

FNP CONSULTORIA \& COMÉRCIO: Agrianual 2004: Anuário da agricultura brasileira, São Paulo, 2004. p.213-215: A potência do álcool nos próximos dez anos.

FRANCO, C. De gole em gole, a cachaça ganha mercado. O Estado de São Paulo. Economia, São Paulo, 24 fev. 2002. p.B-12.

HORII, J. A cana-de-açúcar como matéria-prima. Visão Agrícola, n.1, p.88-93, 2004.

LÉAUTÉ, R. Distillation in alambic. American Journal of Enology and Viticulture, v.41, n.1, p.90-103, 1990.

LIMA, A. de J. B. Variação do emprego de substâncias adsorventes para melhoria da qualidade de cachaça com excesso de cobre. Lavras, 2005. 64p. Dissertação (Mestrado) - Faculdade de Agronomia, Universidade Federal de Lavras.

LIMA, U. de A. Produção nacional de cachaças e potencialidade dos mercados internos e externos. In: MUTTON, M.J.R.; MUTTON, M.A. (Ed.) Aguardente de cana: produção e qualidade. Jaboticabal: Fundação Estadual de Pesquisas Agronômicas, 1992. p.151-163.

LIMA, U. de A. Aguardentes. In: AQUARONE, E.; BORZANI, W.; SCHMIDELL, W.; LIMA, U. de A. (Ed.) Biotecnologia na produção de alimentos. São Paulo: Edgard Blucher, 2001. cap.5, v. 4, p.145-182. (Biotecnologia Industrial) 
LITCHEV, V. Influence of oxidation process on the development of the taste and flavor of wine distilates. American Journal of Enology and Viticulture, v.40, n.1, p.3135, 1989.

LÓPEZ, R. Cachaça amplia potencial de consumo no mercado externo. Engarrafador Moderno, p.18-24, jul.2003. http://www.engarrafadormoderno.com.br/arquivo/110 dr.pdf (17 set. 2004)

MAIA, A.B. Componentes secundários da aguardente. STAB. Açúcar, Álcool e Subprodutos, v.12, p.29-39, jul./ago. 1994.

MEILGAARD, M.; CIVILLE, G.V.; CARR, B.T. Sensory evaluation techniques. 3 ed. New York: CRC Press, 1999. 387p.

MORAES, F.V. Como controlar a qualidade da cachaça. Engarrafador Moderno, v.10, n.85, p.24-29, mai. 2001.

MOSEDALE, J.R.; PUECH, J.L. Wood maturation of distilled beverages. Trends in Food Science \& Technology, v.9, n.3, p.95-101, 1998.

NICOL, D.A. Rum. In: LEA, A.G.H.; PIGGOTT, J.R. (Ed.) Fermented beverage production. 2 ed. New York: Klumer Academic/Plenum Publishers, 2003. cap.12, p.263-287.

NISHIMURA, K., MATSUYAMA, R. Maturation and maturation chemistry. In: PIGGOTT, J.R., SHARP, R., DUNCAN, R.E.B. (Ed.) The science and technology of whiskies. New York: Longman Scientific \& Technical, 1989. p. 235-63. 
NÓBREGA. I.C. da C. Análise dos compostos voláteis da aguardente de cana por concentração dinâmica do "headspace” e cromatografia gasosa-espectrometria de massas. Boletim da Sociedade Brasileira de Ciência e Tecnologia de Alimentos, v.23, n.2, p.210-216, mai./ago. 2003.

NOVAES, F.V. Testes e análises realizados para assegurar a qualidade da cachaça brasileira. Engarrafador Moderno, v.7, n.46, 1996.

PACKOWSKI, G.W. Beverage spirits, distilled. In: KIR-OTHMER (Ed.) Encyclopedia of chemical technology. 3 ed. New York: John Wiley \& Sons, 1978. v.3, p.830-863.

PIGGOTT, J.R.; CONNER, J.M. Whiskies. In: LEA, A.G.H.; PIGGOTT, J.R. (Ed.) Fermented beverage production. 2 ed. New York: Klumer Academic/Plenum Publishers, 2003. cap.11, p.239-262.

PREGNOLATO, W.; PREGNOLATO, N.P. (Coord.) Normas analíticas do Instituto Adolfo Lutz: métodos químicos e físicos para análise de alimentos. 3ed. São Paulo: Instituto Adolfo Lutz, 1985. 533p.

PUECH, J.L. Viellissement du cognac. Sciences des Aliments, v.4, n.1, p.66-80, 1983.

PUECH, J.L. Phenolic compounds in oak wood extracts used in the aging of brandies. Journal of the Science of Food and Agriculture, v.42, n.2, p.165-172, 1988.

REAZIN, G.H. Chemical mechanisms In whiskey maturation. American Journal of Enology and Viticulture, v.32, n.4, p.283-289, 1981.

SALES, A.C. Registro de estabelecimento, equipamentos para produção e controle de operação da fábrica de aguardente. In: CARDOSO, M. das G. (Ed.) Produção de aguardente de cana-de-açúcar. Lavras: Editora UFLA, 2001. cap. 2, p.51-112. 
SAS STATISTICAL ANALYSIS SYSTEM INSTITUTE. Sas/Qc software; usage and reference. 2.ed. Cary, 1996. 2v.

SCHWAN, R.F.; CASTRO, H.A.de; Fermentação. In: CARDOSO, M. das G. (Ed.) Produção de aguardente de cana-de-açúcar. Lavras: Editora UFLA, 2001. cap. 3, p.113-127.

SEFTON, M.A.; FRANCIS, L.I.; WILLIAMS, P.J. Volatile norisoprenoid compounds as constituints of oak woods used in wine on spirit maturation. Journal of Agriculture and Food Chemistry, v.38, n.11, p.2045-2049, 1990.

SHEREV, R.N.; BRINK, J.A. Indústria de fermentação. In: SHEREV, R.N. (Ed.) Indústrias de processos químicos. 4 ed. Rio de Janeiro: Guanabara Dois, 1980. cap.31, p.469-495.

SILVA JÚNIOR., L.S. Avaliação físico-química e sensorial da cachaça durante o envelhecimento em ancorote de carvalho (Quercus sp.) irradiado. Araraquara, 1999. 111p. Dissertação (Mestrado) - Faculdade de Ciências Farmacêuticas, Universidade Estadual Paulista "Júlio de Mesquita Filho”.

SINGLETON, V.L. Maturation of wines and spirits: comparison, facts and hypotheses. American Journal of Enology and Viticulture, v.46, n.1, p.98-115, 1995.

SOUZA, M.D.C.A.; DEL MASTRO, N.L. Irradiation of cane sugar spirit. Radiation Physics and Chemistry, v.57, p.257-259, 2000.

STUPIELLO, J.P. Destilação do vinho. In: MUTTON, M.J.R.; MUTTON, M.A. (Ed.) Aguardente de cana: produção e qualidade. Jaboticabal: FUNEP, 1992. p.67-78.

URBAIN, W.M. Food irradiation. New York: Academic Press, 1986. 351p. 
VARGAS, E.A.; GLÓRIA, M.B. Qualidade da cachaça de cana (Saccharum officinarum, L.) produzida, comercializada e/ou engarrafada no Estado de Minas Gerais. Boletim da Sociedade Brasileira de Ciência e Tecnologia de Alimentos, v.15, n.1, p.43-46, 1995.

VITTI, D.M.S.S.; DEL MASTRO, N.L.; KIKUCHI, O.K.; NOGUEIRA, N.L. Irradiação de resíduos fibrosos com feixes de elétrons: efeitos na composição química e digestibilidade. Scientia Agricola, v.55, p.159-171, 1998.

WALDER, J.M.M.; SPOTO, M.H.F.; NOVAES, F.V.; ALCARDE, A.R. Aging of sugar cane spirit using gamma radiation. In: INTERNATIONAL CONGRESS ON ENGINEERING AND FOOD, 9., Montpellier, 2004. Anais. Montpellier: SCI, 2004. p.937.

YOKOYA, F. Fabricação da cachaça de cana. Campinas: Fundação Tropical de Pesquisas e Tecnologia “André Tosello”, 1995. 92p. 